\title{
Materials Availability for Fusion Power Plant Construction
}

\author{
by \\ J. N. Hartley \\ L. E. Erickson \\ R. L. Engel \\ T. J. Foley
}

September 1976

Prepared for the Energy Research and Development Administration under Contract E(45-1)-1830 
NOTICE

This report was prepared as an account of work sponsored by the United States Government. Neither the United States nor the Energy Research and Development Administration, nor any of their employees, nor any of their contractors, subcontractors, or their employees, makes any warranty, express or implied, or assumes any legal liability or responsibility for the accuracy, completeness or usefulness of any imformation, apparatus, product or process disclosed, or represents that its use would not infringe privately owned rights.

\section{PACIFIC NORTHWEST LABORATORY \\ operated by \\ BATTELLE \\ for the}

ENERGY RESEARCH AND DEVELOPMENT ADMINISTRATION

Under Contract E(45-1)-1830
Printed in the United States of America
Available from
National Technical Information Service
US. Department of Commerce
5285 Port Royal Road
Springfield, Virginia 2215

Price: Printed Copy \$5.50; Microfiche \$2.25 
MATERIALS AVAILABILITY FOR FUSION POWER PLANT CONSTRUCTION

by

J. N. Hartley

L. E. Erickson

R. L. Engel

T. J. Foley

September 1976

Battel le

Pacific Northwest Laboratories

Richland, Washington 99352 


\section{PREFACE}

Fusion reactor technology has developed far enough to expect laboratory demonstration of practical levels of fusion employing the $D-T$ reaction to occur in the early 1980s. Following that demonstration, and depending upon the national priorities for energy from D-T fusion, construction and operation of experimental reactors and demonstration power reactors could occur before the end of this century. Operation of the first commercial power plants could then follow, starting about 2010 .

Development and adoption of a new power system eventually will require a description of the environmental effects in an environmental statement providing a comparison to the effects of competitive systems. In anticipation of that statement, an environmental analysis (BNWL-2010) has been prepared for the ERDA Division of Magnetic Fusion Energy. That analysis estimates the environmental effects of constructing and operating D-T fusion reactors as an economically competitive source of electricity in the 21 st century.

The analysis has four primary purposes:

1. To describe the general nature of the environmental effects,

2. To determine current ability to estimate the effects,

3. To determine methods for reducing the effects, and

4. To determine research necessary for increasing capability to define and reduce the effects.

Timely identification of needed research and methods for reducing effects will permit the performance of that research and the revision of conceptual fusion power plant designs before preparation of the program environmental statement. This would improve the quality of the environmental statements and could reduce the estimated adverse environmental effects due to fusion power plants.

The environmental analysis (BNWL-2010) concludes that the following assumed characteristics are the best set for the first operating fusion power plants:

- The D-T fusion reaction

- Large quantities of activation products

- Kilogram quantities of tritium in the plant systems

- Massive reactor structures

- Large lithium inventories

- Large inventories of liquid metals and salts

- Standard electricity generation - Standard radioactive waste systems - Large magnetic fields

- A self-contained fuel cycle

- Rural siting

Using these characteristics a reference reactor was analyzed to determine the environmental effects by using available concepts of plant subsystems designs that control interactions with the environment or by assumption that best current technology would be used in subsystems design. Because this analys is does not take into account advances in both fusion and waste control technology during the next thirty years, the estimated effects probabiy are significantly higher than the actual effects will be for the first fusion power plants. The estimated environmental effects should be interpreted only as being the probable upper limit for the actual effects. 
Preparation of the fusion power plant environmental analysis required development and use of specially developed data and analysis methods not used in the preparation of current environmental statements for fossil and fission power plants. These data and analysis requirements are documented in a series of reference topical reports to make this information publicly available and to assure understanding of the basis for the conclusions made in the environmental analysis. These reference topical reports summarize the state-of-the-art as applicable to preparation of environmental statements for fusion power plants. They present the data and analytical techniques used in the environmental analysis to estimate the interactions with the environment and the resultant environmental effects. This information then was analyzed for adequacy and the need was determined for additional research to assure satisfactory ability to prepare environmental statements for the fusion development program and experimental facilities in the early 1980s. Estimated environmental effects are presented in these reference documents only as necessary to illustrate use of the data and analytical techniques.

This report is one of those reference documents for the environmental analysis. The other documents in this series contain more details of the power plant concepts and the probable environmental effects of fusion power plants with the assumed characteristics listed above. These documents are available through the National Technical Information Service:

An Environmental Analys is of Fusion Power to Determine Related R\&D Needs, BNWL-2010

Review of Fusion Research Program: Historical Summary and Program Projections, BNWL-2011

Fuel Procurement for First Generation Fusion Power Plants, BNWL-2012

Current Fusion Power Plant Design Concepts, BNWL-2013

Reference Commerical Fusion Power Plants, BNWL-2014

Siting Commercial Fusion Power Plants, BNWL-2015

Materials Availability for Fusion Power Plant Construction, BNWL-2016

Projected Thermodynamic Efficiencies of Fusion Power Plants, BNWL-2017

Tritium Source Terms for Fusion Power Plants, BNWL-2018

Management of Nontritium Radioactive Wastes from Fusion Power Plants, BNWL-2019

Methodology for Estimating Radiation Doses Due to Tritium and Radiocarbon Releases, BNWL-2020

Magnetic Field Considerations in Fusion Power Plant Environs, BNWL-2021

Biological Effects of Tritium Releases from Fusion Power Plants, BNWL-2022

Biological Effects of Activation Products and Other Chemicals Released from Fusion Power Plants, BNWL -2023

Safety Review of Conceptual Fusion Power Plants, BNWL-2024

An Investigation of the Transportation Requirements of Fusion Power Plants, BNWL-2025

Considerations of the Social Impact of Fusion Power, BNWL-2026

Environmental Impacts of Nonfusion Power Systems, BNWL-2027

Environmental Cost/Benefit Analysis for Fusion Power Plants, BNWL-2028

Biomagnetic Effects: A Consideration in Fusion Reactor Development, BNWL-1973

An Analysis of Tritium Releases to the Atmosphere by a CTR. BNWL-1938 
A preliminary assessment was made of the estimated total U.S. material usage with and without fusion power plants as well as the U.S. and foreign reserves and resources, and U.S. production capacity. The potential environmental impacts of fusion power plant material procurement were also reviewed including land alteration and resultant chemical releases. To provide a general measure for the impact of material procurement for fusion reactors, land requirements were estimated for mining and disposing of waste from mining.

The results of this preliminary assessment indicate the following trends:

- Construction of fusion power plants with their massive reactor systems might use tens of thousands of tons of metallic structural materials which might increase the total quantity of some materials used per unit of electrical capacity built.

- Current U.S. and world reserves of many fusion power plant materials are less than their expected U.S. cumulative uses to 2040. However, price increases and/or technological improvements would convert some resources into reserves. Reserve figures do not provide adequate information about material supply because they do not identify the material to be tapped with the next unit of investment. Thus, reserves cannot be used as the only basis for analyzing the avalability of materials for fusion power plants. Information on resources that may become reserves in the future is also relevant.

- U.S. resources of beryllium, chromium, copper, lead, lithium, mercury and nickel are small compared to their possible domestic uses with fusion reactors. Therefore, some fusion power plant materials will probably come from foreign sources. However, this does not necessarily imply that they will not be available. The geographic distribution of some of these materials is so uneven that significant, temporary, price increases for some materials could result from foreign cartels.

- Reported world resources of beryllium, lead, and nickel are less than their expected U.S. cumulative uses to 2040. However, these data do not include large potential resources (for example, nickel in ocean nodules), and resource estimates based on crustal abundance of these metals exceed their expected U.S. cumulative uses to 2040.

- Production capacity at all stages of production is a major factor affecting materials prices in the immediate future. In the long-run capacity is expected to increase significantly in response to material usage for fusion power plant construction and other uses. Sufficient lead time ( 5 to 15 years) must be included when fusion power plant construction schedules are planned to allow for this construction. The use of materials in fusion power plants will influence the optimal rate of capital investment in mining, processing, and fabricating. Therefore, it is very important that the producing industries be made aware of the potential material usage so that they can plan for development of production capacities. 
- The geochemically abundant elements: oxygen, silicon, aluminum, iron, calcium, magnesium sodium, potassium, titanium, hydrogen, manganese, and phosphorus account for $99.2 \%$ of the mass of the earth's crust. The remaining 76 geochemically scarce elements account for only $0.77 \%$ of the mass. The use of the geochemically abundant elements should be encouraged whenever their substitution for less abundant elements results in lower real costs discounted over the time of producing electricity from fusion power plants.

- About $0.16 \mathrm{~km}^{2}$ (40 acres) of land might be altered as a result of the use of materials for constructing a 1000-MWe fusion power plant. Most of this land alteration would be the result of copper, molybdenum and nickel mining and milling operations.

- Materials will probably be available for the construction and operation of fusion power plants, if: 1) historical materials discovery rates continue, 2) improvements are made in the technology of mining, processing, fabricating, and recycling of materials, 3) we are able to accomplish more with less material resources, 4) per capita use of materials declines and 5) the uneven geographic distribution of reserves and resources is not sufficient to allow foreign monopolies or cartels among suppliers.

\section{RESEARCH RECOMMENDATIONS}

This report presents a preliminary estimate of the interaction between materials availability and use for fusion power plant construction and operation. Current knowledge of many aspects of this assessment was found to be very limited. For example, the available information on U.S. and world reserves and resources is limited. Currently estimated U.S. and world reserves and resources of many materials are less than expected U.S. cumulative use including fusion power plant uses. We expect some new resources to be discovered through additional exploration and some resources to become reserves through development of these new resources, through increased prices of these materials and through technological change. However, we do not have good predictions of these future changes. If few additions to reserves occur many materials may not be available for fusion power plants.

To improve the assessment of the materials availability for fusion power plants and of the impacts that the material procurement for fusion power plants have on the environment, we would need improved assessments and projections of: 1) material use rates, 2) the long-run costs of supply (potential for resource depletion), and 3) the associated environmental impacts for each material which is expected to be used for fusion power plant construction and operation. More knowledge of how much of the various materials exist in the earth would be helpful in assessing the availability of materials for fusion power plants. However, knowing where these materials are and in what quantities is only the first step towards determining the future costs of these materials. More information on future changes in the technology of mining, processing, fabricating, and recycling each material would also be needed to determine their long run supply curves. To determine the costs of supply from these long-run supply curves at a given future date, materials use rates at every point in time prior to and including this date would also 
be needed. Finally, the environmental effects of all this future activity including the effects of future technologies would be needed to complete the improvements in this assessment of the effects of materials procurement for fusion power plants on the natural environment.

To determine whether the long-run supply prices for these materials are high enough to cause substitution of other materials in fusion power plant designs would require much more information on the comparative usefulness of various materials in these power plant designs. To determine whether use of materials in fusion power plants will have much effect on their use in other industries would require much more information on the future comparative usefulness of these materials in the other industries. In short, better assessment of the "availability" of materials and the environmental impacts of materials procurement for fusion power plants could usefully involve a much greater effort on each of the areas mentioned above than has been expended in this preliminary assessment. 
$\underline{\text { TABLE OF CONTENTS }}$

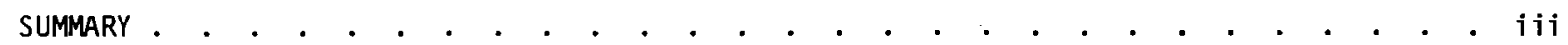

RESEARCH RECOMMENDATIONS . . . . . . . . . . . . . . . . . . . . . . . . . iv

LIST OF TABLES $\quad$ •

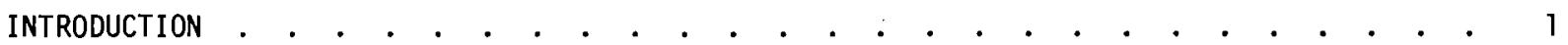

MATERIAL USE FOR POWER PLANT CONSTRUCTION

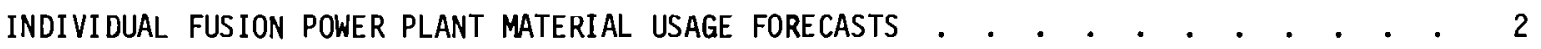

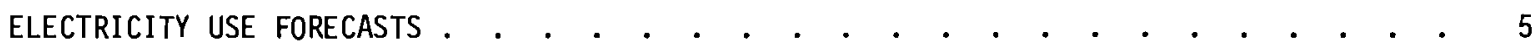

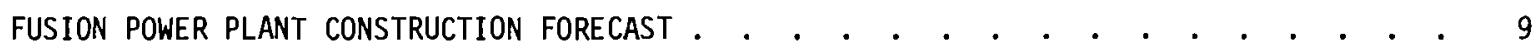

ESTIMATED TOTAL MATERIAL USAGE (WITH AND WITHOUT FUSION POWER PLANTS) • . • • • $\quad 13$

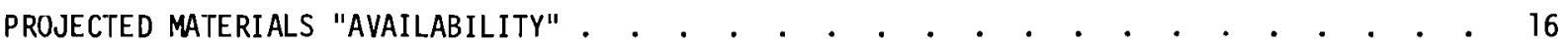

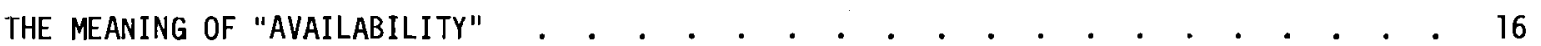

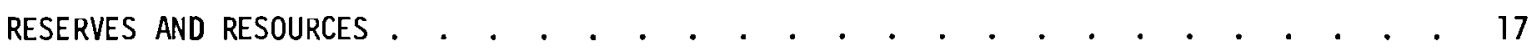

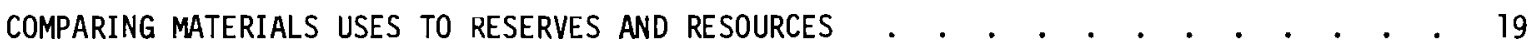

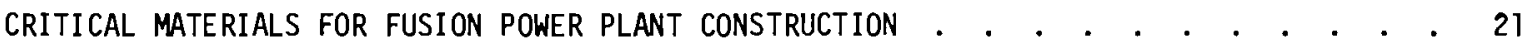

POTENTIAL ENVIRONMENTAL IMPACTS OF MATERIALS PROCUREMENT FOR FUSION POWER PLANTS . $\quad 24$

APPENDIX A: DESCRIPTION OF THE EXPLOR-MULTITRADE PROGRAM . . . . . . . . . . . . . A-1

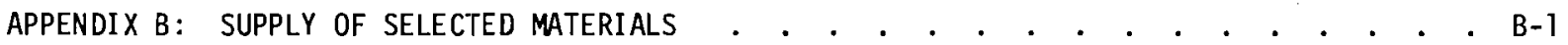

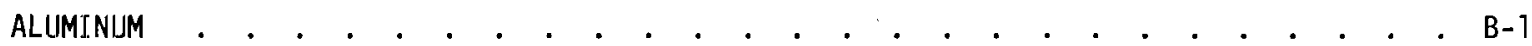

COPPER • . . . . . . . . . . . . . . . . . . . . . . . . . . . . . . .

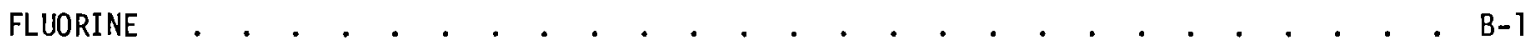

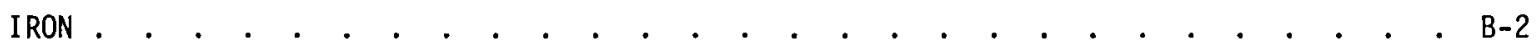

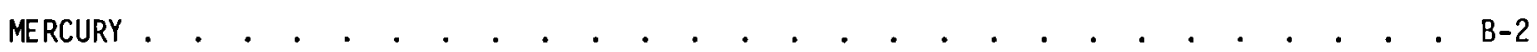

MANGANESE . . . . . . . . . . . . . . . . . . . . . . . . . . . B-3

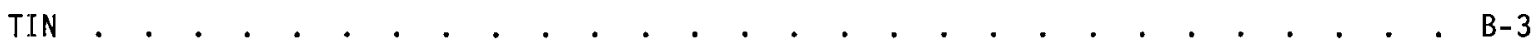

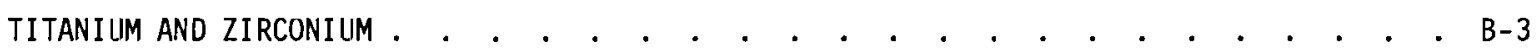

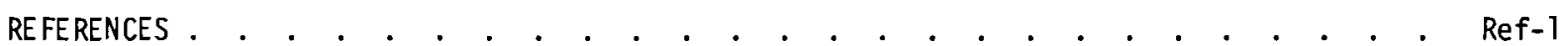

GLOSSARY . . . . . . . . . . . . . . . . . . . . . . . . . . . . . . . . . . . . . . . . . 


\section{$\underline{\text { LIST OF TABLES }}$}

Originators of Conceptual and Reference Fusion Power Plant Designs

Material Usage for Fusion Power Plant Construction . . . . . . . . . . . 3

Average Annual Material Replacement Estimates for Fusion Power Plant . . . . . 4 Normalized Material Usage for Fusion Power Plant Construction . . . . . . . 4 Normalized Average Annual Material Estimates for Fusion Power Plant . . . . . 5 U.S. Electricity Generated by Utilities in the U.S. Historical and Forecasted . . . . . . . . . . . . . . . . . . . . . . . 6 U.S. GNP Forecasts . . . . . . . . . . . . . . . . . . . . . . 7 U.S. Population Forecasts Summary of Linear Programming Cases Solved . . . . . . . . . . . . . 10 Nuclear Fuel Cycle Technology Developments . . . . . . . . . . . . . 10 Total Estimated Present Value of Electricity Production Costs . . . . . . . 11 Estimated Capacity Built (GWe) by Decade . . . . . . . . . . . . . . 11 Estimated Installed Capacity (GWe) at Beginning of Year . . . . . . . . . 12 Estimated Annual Electric Generation by Plant Type . . . . . . . . . . . 12 Estimated Critical Material Usage for Constructing a Hypothetical Fusion Power Plant. . . . . . . . . . . . . . . . . . . . 13

Estimated Domestic Annual Use of Critical Materials Assuming No Fusion Power Plants . . . . . . . . . . . . . . . . . . . . . 14

Estimated Domestic Annual Use of Critical Materials Assuming Introduction of Fusion Power Plants . . . . . . . . . . . . . . . . 14 Total Estimated Domestic Cumulative Use of Critical Materials (1975-2040) . . 15 Change in World Reserves . . . . . . . . . . . . . . . . . . . . 18 U.S. and World Resources, Crustal Abundance, 1974 Reserves, 1974 Production and 1974 Consumption for Fusion Power Plant Construction Materials . . . . . . 19 Critical Fusion Power Plant Materials Uses Versus Current Reserves and Resources . . . . . . . . . . . . . . . . . . . 20

Dates of Depletion of 1974 U.S. Reserves of "Critical" Fusion Power Plant Materials, Assuming No Additions to Reserves . . . . . . . . . . . 20 Ratio of 1975 Cutoff Grade to Crustal Abundance for Selected Minerals . . . . . 21 Summary of Material Availability for Select Fusion Power Plant Materials . . . 21 Quantities of Select Metals Used in the U.S. in 1974 and Percentage Domestically Produced . . . . . . . . . . . . . . . . . . . . 22 Percentage Distribution of 1967 World Mineral Production for Select Materials . $\quad 25$ Estimated Land Alterations for Mining of Materials for Fusion Power Plants . . 27 Technical Coefficients Representing Sales of Critical Materials to 0ther EXPLOR Sectors

\section{LIST OF FIGURES}


MATERIALS AVAILABILITY FOR FUSION POWER PLANT CONSTRUCTION

\section{INTRODUCTION}

Fusion power plants may have unique materials use characteristics for both the plant construction and the fuel cycle. This report presents the results of a preliminary assessment of the use and availability of construction materials for fusion power plants as well as the potential environmental impacts associated with the production of these materials.

The materials used to build fusion power plants are estimated by multiplying the normalized material use per unit power capacity by the estimated total fusion power plant capacity. Fusion power plant capacity is estimated by extending existing electrical use forecasts and assuming that fusion power plants will be able to produce electricity at a lower cost than fission or fossil plants. The fusion power plant estimated cumulative materials usages are then compared with total estimated cumulative use of each material without the fusion power plants as well as reserves and resources for each material.

Preliminary estimates indicate that fusion power plants may use larger quantities of construction materials than do fission or fossil fuel plants of the same megawatt electric (MWe) capacity. The conceptual fusion power plants have massive structures containing tens of thousands of tons of stainless steel, copper and lead. Also, large quantities of less commonly used materials may be used in fusion power plants, such as niobium, beryllium and titanium. The use of these materials may substantially affect the environment and may increase the probability of dramatic price increases for specific materials.

The material use estimates in this analysis should not be interpreted as the actual use for commercial fusion power plants. Because they are based on plant designs not optimized for minimum material use or electricity costs, future technological advances are expected to reduce substantially the material use per unit of generating capacity.

This report contains three sections. The first section estimates the quantity of materials expected to be used for fusion power plant construction. Estimates are made of the amount of construction materials used per unit of electricity generation capacity at fusion power plants, the total generation capacity expected to be built in the United States through 2040, the portion of this generation capacity that would be provided by fusion power plants, and finally the total amounts of materials of interest that would be used in the United States with and without fusion power plants.

The second section investigates the "availability" of these construction materials. "Availability" is defined in this section and in the glossary. Both reserves and resources in the U.S. and the world are compared to the expected U.S. cumulative use to 2040 of selected materials with and without fusion power plants.

The last section estimates the general environmental effects of materials procurement for fusion power plants. A glossary defines the key terms used in this report. 
Large quantities of materials may be used in fusion power plant construction and operation because of the large physical size of the conceptual fusion power plants and the supporting systems. The primary use of large quantities of minerals would be in the construction of these facilities. After plant operations begin a smaller quantity would be needed, primarily for replacement of the inner walls.

The total quantity of materials used for construction depends on the estimated types and numbers of fusion power plants to be built. The estimated material usage by fusion power plants that might be constructed as described in this section as well as the estimated number of fusion power plants which is based on electricity use forecasts presented in this section.

\section{INDIVIDUAL FUSION POWER PLANT MATERIAL USAGE FORECASTS}

In this study the amounts of material used per unit of power generation is based on the normalized usage for the six fusion power plant concepts for which sufficient data is available for material usage estimates. Although this report makes no attempt to evaluate the best way to use materials for any fusion power plant concept, it does identify some problems in materials availability. The originators of these conceptual fusion power plants are listed in Table 1.

TABLE 1. Originators of Conceptual and Reference Fusion Power Plant Designs

\begin{abstract}
Magnetic Confinement Fusion Reactors
\end{abstract}

Tokamak

Theta Pinch

Mirror

\author{
Brookhaven National Laboratory (BNL) \\ Oak Ridge National Laboratory (ORNL) \\ Princeton Plasma Physics Laboratory (PPPL) \\ University of Wisconsin \\ Los Alamos Scientific Laboratory (LASL) \\ Lawrence Livermore Laboratory (LLL)
}

This material "availability" analysis is made for a typical power plant on an individual material basis. Magnetic confinement designs are the only fusion power plant designs developed well enough to use in making material use estimates. Thus, materials used for the construction and operation of individual conceptual fusion power plants were estimated for the magnetic confinement design as shown in Tables 2 through 5. The normalized uses of construction materials for the fusion power plant design concepts for which material information is available are presented in Table 4. This materials information includes the entire power plant only for UWMAK-I and the PPPL Tokamak. Therefore, the materials usage estimates selected as a basis for this analysis are the maximum values shown in Table 4 for the UWMAK-I and PPPL power plants. 
TABLE 2. Material Usage for Fusion Power Plant Construction*

\begin{tabular}{|c|c|c|c|c|c|c|c|c|c|c|c|}
\hline \multirow[b]{2}{*}{ Element } & \multicolumn{11}{|c|}{ Material Usage, Metric Tons } \\
\hline & $\begin{array}{l}\text { Nuclear } \\
\text { Island (h) }\end{array}$ & $\begin{array}{l}\text { UWMAK-I (a) } \\
\begin{array}{c}\text { Balance } \\
\text { Plant }(i)^{f}\end{array} \\
\end{array}$ & Total & $\begin{array}{l}\text { Nuclear } \\
\text { Island }\end{array}$ & $\begin{array}{c}\text { ULMAK-II } \\
\text { Balance of } \\
\text { Plant } \\
\end{array}$ & Iotal & $\begin{array}{l}\mathrm{PPPL}^{(\mathrm{c})} \\
\text { Total } \\
\end{array}$ & $\begin{array}{l}\text { ORML (d) } \\
\text { Nuclear } \\
\text { Island } \\
\end{array}$ & $\begin{array}{l}\text { Theta } \\
\text { Pinchle) } \\
\text { Total } \\
\end{array}$ & $\begin{array}{l}\text { Mirror }(f) \\
\text { Reactor and } \\
\text { Convertor }(j)\end{array}$ & $\begin{array}{c}\text { BNL Blanket (g) } \\
\text { Blanket and } \\
\text { Shield } \\
\end{array}$ \\
\hline Aluminum & 347 & 445 & 792 & 4,766 & 20 & 4,786 & 17 & & & & 2,488 \\
\hline Boron & 1,580 & & 1,580 & 4,280 & & 4,280 & & & & & 5,790 \\
\hline Beryllium & & & & 985 & & 985 & 875 & & 50 & & 189 \\
\hline Carbon & 446 & & 446 & 4,890 & & 4,890 & & 1,100 & 680 & 233 & 3,138 \\
\hline Chromium & 5,490 & 6.199 & 11,689 & 5,825 & 3,605 & 9,430 & 1.658 & 36 & & 7,506 & \\
\hline Copper & 7,466 & 3,259 & 10,725 & 10,692 & 676 & 11,368 & 3,264 & 450 & 9,300 & 8,810 & \\
\hline Iron & 18,872 & 95,924 & 114,796 & 29,229 & 78,527 & 107,756 & 11,921 & 6,424 & & 24,770 & \\
\hline Hel ium & 58 & 80 & 138 & 69 & 22 & 91 & 117 & 1 & 1,200 & & \\
\hline Magnes ium & & 3 & 3 & & & & & & & & \\
\hline Potass ium & & & & & & & & 10 & & & \\
\hline Lithium & 1,700 & & 1,700 & 980 & & 980 & 598 & 460 & $1,600^{(k)}$ & 83 & $60(\mathbf{k})$ \\
\hline Manganese & 607 & 608 & 1,215 & 937 & 355 & 1,292 & 164 & & & 751 & \\
\hline Molybdenum & 579 & 22 & 601 & 917 & 92 & 1,009 & 288 & & & & \\
\hline Sodium & & 17,826 & 17,826 & & 9,816 & 9,816 & & & & & \\
\hline Niobium & 101 & 39 & 140 & 145 & 7.5 & 153 & 102 & 1,000 & 3,600 & & \\
\hline Nickel & 4,221 & 4,484 & 8,705 & 6,480 & 2,480 & 8,960 & 1,647 & 28 & & 4,504 & \\
\hline Lead & 20,500 & & 20,500 & 19,800 & & 19.800 & & 5,350 & & 1,272 & \\
\hline $\operatorname{Tin}$ & & & & & & & 34 & & 300 & & \\
\hline Tritium & 52 & 20 & 72 & & & & 17 & 642 & & & \\
\hline Yttrium & & 5 & 5 & & 3 & 3 & & & & & \\
\hline Zirconium & & 100 & 100 & & 100 & 100 & 1 & 1 & & & \\
\hline Concrete & & 680,000 & 680,000 & & & & 32,000 & 20,000 & & 38,200 & \\
\hline
\end{tabular}

* In addition to the sources indicated in footnotes $a-f$, the following powerplant designs were consulted but did not include information on material requirements:

J. Williams, T. Merson, F. Finch, F. Schilling, and T. Frank, "A Conceptual Laser Controlled Thermonuclear Reactor Power Plant," CONF-740402-P1, Proceedings of the First Topical Meeting on the Technology of Controlled Nuclear Fusion, San A. P. Fraas, "Conceptual Designs of a Series of Laser-Fusion Power Plants of 100 to $300 \mathrm{MW}(\mathrm{e})$," presented at the 9th Intersociety Energy Conversion Engineering Conference, San Francisco, CA, August 26-30, 1974. (The "Blascon" concept.)

J. Hovingh, J. Maniscalco, M. Peterson, and R. W. Werner. "The Preliminary Design of a Suppressed Ablation LaserInduced Fusion Reactor," CONF-740402-P1, Proceedings of the First Topical Meeting on the Technology of Controlled Thermonuclear Fusion, San Diego, CA, April 16-18, 1974. (The "Suppressed Abiation" concept.)

(a) 8. Badger et al. (22 authors), Uhak-1, A Wiscons in Toroidal

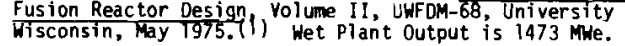

(b) B. Badger et a1., (30 authors), Uwak-II, A Conceptua) Tokamak Power Reactor Design, UWFDM-112, University of Wisconsin, Oc tober 1975.(2)

(c) A Fusion Power Plant, R. G. Mills Ed., MATT-1050, Princeton PTasma Physics Laboratory, 1974. (3) Does not include requirements for smiall components such as valves, pumps, electrical equipment. Net Plant Output is 2030 Mile.

(d) A. P. Fraas, Conceptual Design of the Blanket and Shield Region and Related Systems for a Full Scale Toroidal Fusion Reactor, ORNL-TM-3096, May 1975

(e) J. E. Draley, R. A. Krakowski, T. A. Coultas, and V. A. Maroni An Eng ineering Design Study of a Reference ThetaPinch Reactor (RTPR): Environmental Impact Study, LA-5336, elements only. Net plant output is 4100 me.

(f) R. W. Werner, G. A. Carlson, J. Hovingh, J. D. Lee, ano M. A. Petersan. Progress Report 2 on the Design Considerations for a Low Power Experimental Mirror Fusion Reactor. UCRL-74054-2, September 1973. As emphasized by the title, this design is for an experimental device of low power. Optimization for power production would be expected to introduce economics of scale reducing some of the material requirements per Mhe. Covers blanket and shield, Cu for coils, 304 SS coil support structure and direct convertor structure. Superconductor for coils not included. Net plant output is 170 MWe.

(g) J. R. Powell, Ed., "Preliminary Reference Design of a Fusion Reactor Exhibiting Very Low Residual Radioactivity. " BNL-19565, Brogkhaven National Laboratories. BNL-19565, Broqk (7) Net Plant Output is 1605 ine.

(h) Only construction materials included here (differs from tabulation in source). Tabulation includes all material within toroidal magnets, plus divertor and vertical field coils, injectors, and entire primary coolants.

(i) Not including turbine, reheaters, control room, cooling towers and electrical switch gear. Not including tritium extraction equipment except yttrium.

(j) These requirements were not developed in the design document. Blanket and shield requirements were calculated from the spherical shell neutronics model; coll requirements and materials for coil support and for the direct convertor structure were calculated from descriptions and dimensions, by G. A. Carlson. 6 )

(k) Feedstock for $6_{L i}$ enrichment included. 
TABLE 3. Average Annual Material Replacement Estimates for Fusion Power Plants

Average Annual Replacement Quantities, metric tons

\begin{tabular}{|c|c|c|c|c|c|c|}
\hline \multirow[b]{2}{*}{ Element } & \multicolumn{2}{|c|}{ Average Annual } & \multicolumn{4}{|c|}{ Replacement Quantities, metric tons } \\
\hline & UWMAK -1 (a) & $P P P_{L}(\mathrm{~b})$ & $\mathrm{ORNL}^{(c)}$ & $\begin{array}{l}\text { Thet } \\
\text { Pinchld) }\end{array}$ & Mirror (e) & $\begin{array}{c}\text { BNL } \\
\text { Blanket }(f)\end{array}$ \\
\hline Aluminum & 7.2 & & & & & 252 \\
\hline Beryll fum & & & & 10 & & 1 \\
\hline Carbon & & & 110 & 140 & 11 & 174 \\
\hline Chromium & 129 & 39 & & & 6.3 & \\
\hline Copper & 7.2 & & & 2 & & \\
\hline Iron & 445 & 85 & & & 20 & \\
\hline Hellum & & & & 1 & & \\
\hline Lithium & & & & 16 & & 5 \\
\hline Manganese & 14 & & & & 0.6 & \\
\hline Molybdenum & 14 & & & & & \\
\hline Niobium & & & 14 & 77 & & \\
\hline Nickel & 100 & 94 & & & 3.8 & \\
\hline 21rconium & & & 0.1 & & & \\
\hline
\end{tabular}

(a) Due to 316 sS replacement. $32 \%$ due to biannual replacement of inner blanket; $68 \%$ due to replacement of remainder of blanket every 10 years.

(b) Due to Pe-16 replacenent; one-fif th of blanket each year.

(c) Replace bianket every 10 years.

d) Replace one-fifth of blanket modules each year.

Blanket life is not estimated in the design. 304 ss structure and first wall loading are simtlar to UwAK-1. This table is based upon replacement schedule postulated by rough analogy to ULmak-I. Replacement of inner $30 \mathrm{~cm}$ of blanket every 2 years; replacement of outer $70 \mathrm{~cm}$ of blanket every 10 years; 30-year plant iffe.

(f) Replace one-third of blanket modules each year.

TABLE 4. Normalized Material Usage for Fusion Power Plant Construction*

\begin{tabular}{|c|c|c|c|c|c|c|c|c|}
\hline \multirow[b]{2}{*}{ Element } & \multicolumn{8}{|c|}{ Metric Tons/Mue } \\
\hline & $\begin{array}{l}\text { UWMAK-I (a) } \\
\text { TotaI }\end{array}$ & $\begin{array}{l}\text { PPpL }(b) \\
\text { Total } \\
\end{array}$ & $\begin{array}{l}\text { ORNL }(c) \\
\text { Nuclear } \\
\text { Island } \\
\end{array}$ & $\begin{array}{l}\text { Theta } \\
\text { Pinch(d) } \\
\text { Total }\end{array}$ & $\begin{array}{l}\text { Mirror }(e) \\
\text { Reactor and } \\
\text { Convertor }\end{array}$ & $\begin{array}{c}\text { BNL Blanket }(\mathrm{f}) \\
\text { Blanket and } \\
\text { Shield } \\
\end{array}$ & $\begin{array}{l}\text { Reference } \\
\text { Envelope } \\
\text { Maximum } \\
\text { Matimut }\end{array}$ & $\begin{array}{l}\text { Typical } \\
\text { LMFBR } \\
\end{array}$ \\
\hline Aluminum & 0.54 & 0.008 & & & & 1.55 & $1.6(f)$ & 0.92 \\
\hline Boron & 1.07 & & & & & 3.61 & $3.6(f)$ & \\
\hline Beryllium & & 0.43 & & 0.012 & & 0.12 & $0.4^{(t)}$ & \\
\hline Carbon & 0.30 & & 2.12 & 0.17 & 1.4 & 1.96 & $2.7(c)$ & \\
\hline Chromium & 7.92 & $0.82^{\prime}$ & 0.07 & & 44 & & $44(e)$ & 0.4 \\
\hline Copper & 7.27 & 1.61 & 0.87 & 2.27 & 52 & & ${ }_{53}(e)$ & 0.7 \\
\hline Iron & 77.8 & 5.87 & 12.4 & & 146 & & $146(e)$ & 34 \\
\hline Helium & 0.09 & 0.06 & 0.002 & 0.29 & & & $0.3(d)$ & \\
\hline Magnes ium & 0.002 & & & & & & $0.002(a)$ & \\
\hline Potassium & & & 0.02 & & & & $0.02(c)$ & \\
\hline Lithium & 1.15 & 0.29 & 0.89 & 0.39 & 0.49 & 0.04 & $1.2^{(0)}$ & \\
\hline Manganese & 0.82 & 0.08 & & & 4.4 & & $4.4(e)$ & \\
\hline Molybdenum & 0.41 & 0.14 & & & & & $0.4(a)$ & \\
\hline Sodium & 12.1 & & & & & & $12.1^{(a)}$ & \\
\hline Niobium & 0.09 & 0.05 & 1.93 & 0.88 & & & 1.9 (c) & \\
\hline Nicke1 & 5.90 & 0.81 & 0.05 & & 27 & & $27(e)$ & 0.3 \\
\hline Lead & 13.9 & & 10.3 & & 7.5 & & $13.9(a)$ & 0.046 \\
\hline Tin & & 0.02 & & 0.07 & & & $0.07(d)$ & \\
\hline Titanium & 0.05 & 0.008 & 1.24 & & & & $1.24(\mathrm{c})$ & \\
\hline Yttrium & 0.003 & & & & & & $0.003^{(a)}$ & \\
\hline Zirconium & 0.07 & 0.0005 & 0.002 & & & & $0.07(a)$ & \\
\hline Concrete & 461 & 15.8 & 38.6 & & 225 & & $461^{(a)}$ & 200 \\
\hline
\end{tabular}

* See Footnotes to Table 2.

+ Maximum quantities are from designs correspondingly labeled. 
TABLE 5. Normalized Average Annual Material Replacement Estimates for Fusion Power Plants*

\begin{tabular}{|c|c|c|c|c|c|c|c|}
\hline Element & UWMAK-I (a) & $\mathrm{PPPL}^{(\mathrm{b})}$ & $\mathrm{ORNL}^{(\mathrm{C})}$ & $\begin{array}{l}\text { Mwe } \\
\text { Theta } \\
\text { Pinch(d) }\end{array}$ & Mirror $(e)$ & $\begin{array}{c}\mathrm{BNL} \\
\text { Blanket }\end{array}$ & $\begin{array}{l}\text { Reference- } \\
\text { Envelopet } \\
\text { Maximum }\end{array}$ \\
\hline Aluminum & 4.9 & & & & & 157 & $157^{(f)}$ \\
\hline Beryllium & & & & 2.4 & & 0.6 & $2.4^{(d)}$ \\
\hline Carbon & & & 212 & 34 & 66 & 108 & $212(c)$ \\
\hline Chromium & 87 & 19 & & & 37 & & $87(a)$ \\
\hline Copper & 4.9 & & & 0.5 & & & $4.9(a)$ \\
\hline Iron & 302 & 42 & & & 118 & & $302^{(a)}$ \\
\hline Helium & & & & 0.2 & & & $0.2^{(d)}$ \\
\hline Lithium & & & & 3.9 & & 3 & $3.9^{(d)}$ \\
\hline Manganese & 9.5 & & & & & & $9.5(a)$ \\
\hline Molybdenum & 9.5 & & & & 3.7 & & $9.5(a)$ \\
\hline Niobium & & & 27 & 19 & & & $27(c)$ \\
\hline Nickel & 68 & 46 & & & 22 & & $68^{(a)}$ \\
\hline Zirconium & & & 0.3 & & & & $0.3^{(c)}$ \\
\hline
\end{tabular}

* See Footnotes to Table 2

+ Maximum quantities are from designs correspondingly labeled.

Material usage estimates for UWMAK-II are given in Table 2 for comparison only since this data was not available when this analysis was made. The estimated materials to be used for the LMFBR are included in Table 4 for comparison purposes.

\section{ELECTRICITY USE FORECASTS}

A large number of electricity-use forecasts have been prepared over the years and all were based, in some way, on historical experience. Some forecasts are based directly on the historical pattern of electricity use while others relate this electricity use to variables such as income or population. The available electricity forecasts have differences which are related to historical periods studied as well as various assumptions used in estimating future deviations from the patterns in those base periods. Of these forecasts, four that covered the range of currently credible future electrical use possibilities were selected for analysis. Since these forecasts did not go beyond the year 2000, they were extended to 2040 with methods which were as consistent as possible with the procedures originally used to generate the forecasts.

The electricity use forecasts are given in Table 6 and are illustrated in Figure 1. Compared to 1.5 trilition $\mathrm{kW}-\mathrm{hr}$ (kilowatt hours) in 1970, these forecasts range from 3.4 to 9.7 trillion $\mathrm{kW}-\mathrm{hr}$ in the year 2000 and from 5.6 to 73.3 trillion $\mathrm{kW}-\mathrm{hr}$ by 2040 . Forecasts I and II, which extend the high and low forecasts of the ERDA Assistant Administrator for Planning and Analysis, ${ }^{(8)}$ are similar to the LMFBR medium and low cases, respectively. ${ }^{(9)}$ Forecast III uses a relationship of electricity use to GNP given by Cochran (i0) in a recent critique of the LMFBR impact statements. Forecast IV extends the Zero Energy Growth (ZEG) Case found in the final report of the Ford Foundation's Energy Policy Project. (11) 
TABLE 6. U.S. Electricity Generated by Utilities in the U.S. Historical and Forecasted

\begin{tabular}{|c|c|c|c|c|}
\hline & $\begin{array}{c}\text { Forecast } \\
\mathrm{I} \\
\end{array}$ & & $\begin{array}{l}\text { Forecast } \\
\text { III } \\
\end{array}$ & $\begin{array}{c}\text { Forecast } \\
\text { IV }\end{array}$ \\
\hline & & (trillion & kW-hr) & \\
\hline 1920 & & & 0.039 & \\
\hline 1930 & & & 0.091 & \\
\hline 1940 & & & 0.142 & \\
\hline 1950 & & & 0.329 & \\
\hline 1960 & & & 0.755 & \\
\hline 1970 & & & 1.532 & \\
\hline 1975 & - & - & - & 2.0 \\
\hline 1980 & 3.08 & 2.79 & 2.43 & - \\
\hline 1985 & - & - & - & 2.68 \\
\hline 1990 & 5.62 & 4.56 & 3.49 & - \\
\hline 2000 & 9.67 & 7.00 & 4.77 & 3.44 \\
\hline 2010 & 16.57 & 10.50 & 6.38 & 3.89 \\
\hline 2020 & 27.92 & 15.19 & 8.37 & 4.38 \\
\hline 2030 & 45.63 & 21.37 & 10.76 & 4.94 \\
\hline 2040 & 73.29 & 28.90 & 13.37 & 5.57 \\
\hline
\end{tabular}

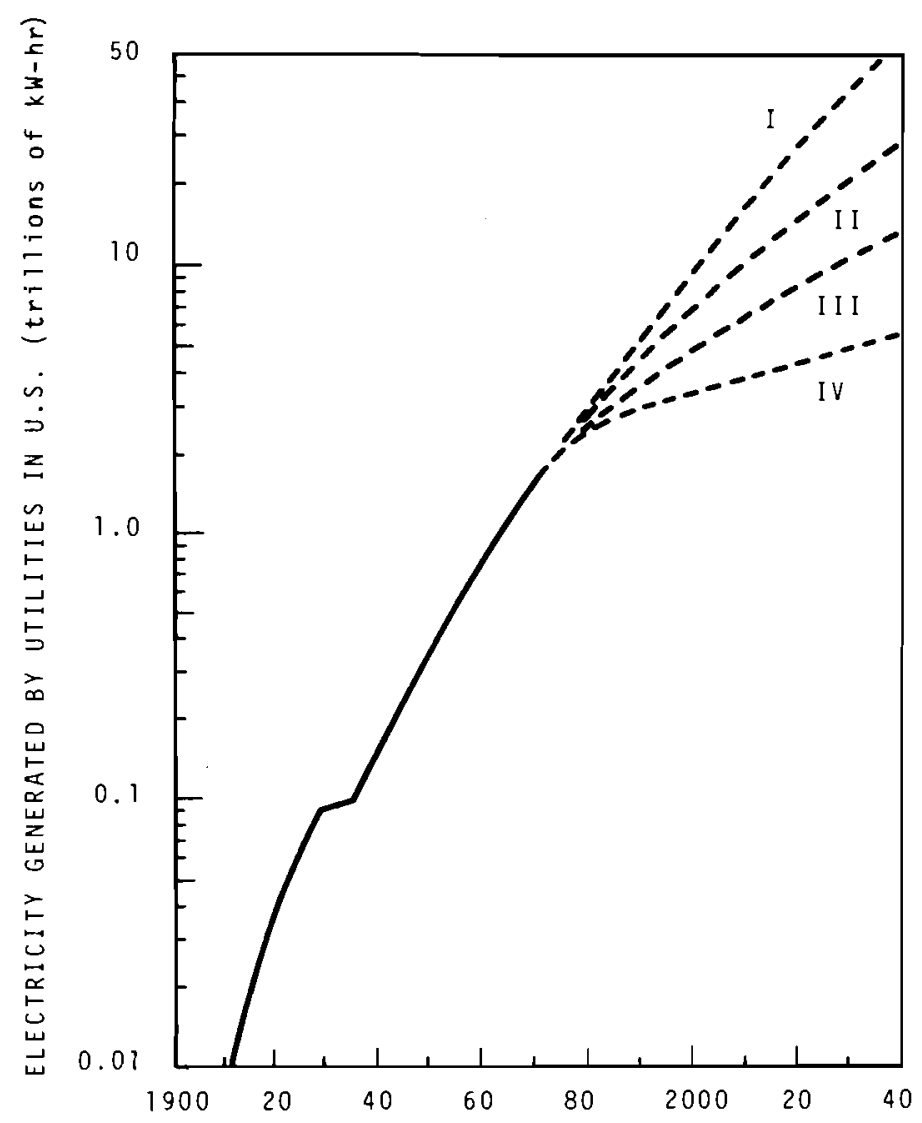

FIGURE 1. U.S. Electricity Use, Historical and Forecasts 
Recent econometric literature indicates that the long-run income elasticity of demand for electricity is about 1.1. (12) The following relationship was found to approximately replicate the ERDA-P\&A forecasts for the 1970 to 2000 period:

$$
\text { Electricity Use }=A(\text { GNP })^{1.1}
$$

where $A$ is not a constant. The value of $A$ was found to follow an approximately linear trend from 1950 to 1970. The future values of $A$ were taken from a linear extrapolation of this trend. While this is not a procedure that we would use to develop new electricity forecasts, it did approximately replicate the forecasts of ERDA-P\&A. The above procedure was used to extend their high and low forecasts to 2040. It is recognized that the results may be little better than direct extrapolation of electricity use.

GNP forecasts for Forecasts I and II were made using the following assumptions: Forecast I uses the Bureau of Census' Series I population forecast to $2040,{ }^{(13)}$ a $2.5 \%$ annual growth rate in GNP/worker $(14)$ and $45 \%$ of the population employed. Forecast II uses the Bureau of the Census' Series II population forecast, ${ }^{(13)}$ a $1.8 \%$ annual growth rate of GNP/worker ${ }^{(14)}$ and $45 \%$ of the population employed. The resulting GNP forecasts used are given in Table 7 , while the population forecasts used are given in Table 8.

TABLE 7. U.S. GNP Forecasts

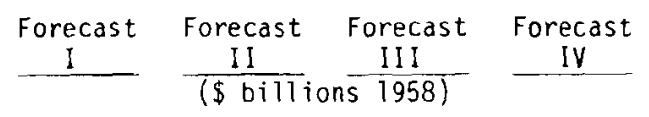

TABLE 8. U.S. Population Forecasts

$$
\begin{aligned}
& \text { Forecast Forecast Forecast Forecast } \\
& \frac{1}{11} \frac{111}{(\$ \mathrm{mi} 17 \mathrm{ions})}-\text { IV }
\end{aligned}
$$

1920

1930

1940

1950

1960

1970

1975

1980

1985

1990

2000

2010

2020

2030

2040

$\begin{array}{rrr} & & 139 \\ & & 181 \\ & & 230 \\ & & 355 \\ & & 488 \\ & & 722 \\ & & - \\ - & - & 1026 \\ 1099 & 1006 & - \\ - & - & 1376 \\ 1600 & 1323 & 1800 \\ 2278 & 1697 & 2333 \\ 3278 & 2165 & 2991 \\ 4717 & 2712 & 3784 \\ 6705 & 3364 & 4647 \\ 9436 & 4050 & \end{array}$

\section{9}

181

230

355

488

722

-
026

-

1800

2333

2991

3784

4647

1018
-
1434
-
2279
3032
3991
5156
6504

$\begin{array}{rrrr} & & 106 \\ & & 123 & \\ & & 133 & \\ & & 151 & \\ & & 179 & \\ & & 205 & \\ & & - & - \\ - & & - & - \\ 226 & 223 & 223 & - \\ - & - & 236 \\ 258 & 245 & 245 & - \\ 287 & 262 & 262 & 265 \\ 322 & 279 & 279 & 279 \\ 362 & 294 & 294 & 294 \\ 403 & 304 & 304 & 304 \\ 449 & 312 & 312 & 312\end{array}$


Forecast III uses the following relationship attributed to Milton Searl in Cochran: (10)

Electricity use $=2.03$ GNP -666

where

Electricity use is in billions of $\mathrm{kW}-\mathrm{hr}$

and

GNP is in billions of 1958 dollars

This relationship was estimated by Searl from 1947 to 1969 data. GNP forecasts for Forecast III were made by assuming a $2 \%$ annual growth rate in GNP/worker, the Bureau of the Census' Series II (13) population forecast, and $45 \%$ of the population employed.

Historically, national income per person employed has grown at an annual rate of $1.9 \%$ from 1929 to 1969. Within this period the rate of growth varied from $1.4 \%$ during the 1929 to 1941 period to $2.5 \%$ during the 1953 to 1964 period. (14) Thus, the GNP/worker growth rate used in Forecast I reflects the highest historical experience while Forecasts II and III use rates near the long-term historical average.

Forecast IV extends the ZEG case of the Ford Foundation's Energy Policy Project. (11) This case assumes total energy use will peak at 100 quadrillion Btus before 1990 . The Census Bureau's Series E population forecast was used by the Ford Foundation while the similar and newer Series II (14) was used to extend this work. In this energy forecast GNP/worker was expected to grow at $2.5 \%$ annual $7 y$ from 1975 to 1985 and $2.35 \%$ from 1985 to 2000 . Therefore, a $2.25 \%$ annual growth rate from 2000 to 2040 is assumed here in extending their work. The Ford Foundation's ZEG case projects the percentage of total energy going to electricity to increase from $27 \%$ in 1975 to $30.5 \%$ in 1985 and $36.5 \%$ in 2000 . An annual growth rate of $1.2 \%$ in the percentage of total energy going to electricity derived from these figures was used to bring this fraction to $58.5 \%$ by the year 2040 . The constant conversion efficiency of 32.3 assumed in the Ford Foundation report (11) was also used here.

0ther forecast results to the year 2000 are included for comparison. The Federal Power Commission in its 1970 National Power Survey ${ }^{(15)}$ forecasts U.S. electricity use of 3.07 trillion $\mathrm{kW}-\mathrm{hr}$ in 1980 and 5.83 trillion $\mathrm{kW}-\mathrm{hr}$ in 1990. A 1973 National Power Survey report extended these results to forecast 10.2 trilition $\mathrm{kW}-\mathrm{hr}$ by the year 2000. (16) These FPC forecasts are close to the Forecast I given here.

A recent survey of energy forecasts shows that electric energy consumption was expected to grow at the annual rate of $5.8 \%$ from 1970 to 1980 and $4.8 \%$ for the 1980 to 2000 period, while total energy use was expected to increase at 3.3\%/year for the 1970-80 period. (17-19) This would result in 2.7 trillion $\mathrm{kW}-\mathrm{hr}$ in 1980 and 6.9 trillion $\mathrm{kW}-\mathrm{hr}$ in 2000 , which is close to the Forecast II presented here. Forecast II was arbitrarily selected as the case to be used as the base for other estimates in this report.

A recent set of state level electricity forecasts, based on econometric analyses of the demand for electricity, was produced by Tyrrel1 at ORNL. (20) He used estimates of the responses of electricity use to changes in the prices of electricity, natural gas, and appliances as well 
as income and population size from an earlier ORNL study. (21) He then combined these estimates with forecasts of these independent variables to produce a "base case" forecast of electricity use. Tyrrell tested the sensitivity of the results to these assumptions and found that the impacts of different electricity price and per capita income assumptions were the most significant. He also found that constant electricity prices would mean electricity use of 6.6 trillion $\mathrm{kW}-\mathrm{hr}$ in 2000 compared to only 2.8 trillion $\mathrm{kW}-\mathrm{hr}$ if electricity prices double and 4.3 trillion $\mathrm{kW}-\mathrm{hr}$ in his base case. Tyrrell's base case is close to the Forecast III presented here.

In a more recent book ${ }^{(22)}$ Uri used the same general procedures used in the earlier ORNL work but obtained different results. Uri's assumptions regarding the future course of electricity prices, population, and income are the same as Tyrrell's while his assumed rate of the natural gas price increase is less than Tyrrell's. Uri's commercial and industrial electricity use growth estimates are so far below Tyrrell's that his total electrical usage forecasts fall below Tyrrell's for all regions in spite of Uri's generally higher residential electricity forecasts. Uri expects the commercial sector to use less electricity in 1990 than in 1970 in most regions because of the high price elasticity he found in the commercial sector. For 1990 Uri forecasts electricity use to be 2.6 trillion $\mathrm{kW}-\mathrm{hr}$ which is considered to be the lowest electricity forecast available and is less than Forecast IV.

Forecasts I through IV cover the range of possibilities that are considered most likely. This allows testing the sensitivity of the impacts of fusion power plants to changes in a wide variety of electrical use forecasts.

\section{FUSION POWER PLANT CONSTRUCTION FORECAST}

To evaluate the long-range role of fusion power plants a computer simulation system ${ }^{(23)}$ was used to estimate the pattern of the electricity generation industry's lony-range development on a multi-regional basis. The model simulates the industry's process of determining what types of plants to build and when to build them. The model finds the smallest present worth system cost, subject to many constraints which 1 imit decisions. Linear programming was used and the system costs are those for both construction and operation.

This analysis consists of six cases covering the four electrical energy use forecasts described in the previous section; the six cases are summarized in Table 9. Cases 1 through 4 correspond to Forecasts I through IV presented in the previous section. In these cases it is assumed that a fusion power plant could be introduced in 2010 at an electricity cost of $3 \%$ less than the LMFBR. Case 5 represents Forecast II electric energy use with a 10\% lower cost assumed for the fusion power plant while Case 6 represents the Forecast II electric energy use without any fusion power plants. The reference nuclear assumptions include new technologies according to the estimated dates of their first commercial use as shown in Table 10. Fusion power plants were introduced into the analysis assuming that construction of one plant was completed in 2010 with the building rate doubling every 2 years or as constrained by projected economic conditions. 
TABLE 9. Summary of Linear Programming Cases Solved

\begin{tabular}{|c|c|c|c|c|}
\hline Case & $\begin{array}{c}\text { Fusion } \\
\text { Reactor } \\
\text { Introduction } \\
\end{array}$ & $\begin{array}{c}\text { Electricity } \\
\text { Use } \\
\text { Forecast } \\
\end{array}$ & $\begin{array}{l}\text { Fusion Reactor } \\
\text { Electricity } \\
\text { Cost \% of LMFBR }\end{array}$ & $\begin{array}{c}\text { Fusion } \\
\text { Reactors }\end{array}$ \\
\hline 1 & 2010 & I & 97 & Reference \\
\hline 2 & 2010 & II & 97 & Reference \\
\hline 3 & 2010 & I I I & 97 & Reference \\
\hline 4 & 2010 & IV & 97 & Reference \\
\hline 5 & 2010 & II & 90 & Reference \\
\hline 6 & -- & II & - & Reference \\
\hline
\end{tabular}

TABLE 10. Nuclear Fuel Cycle Technology Developments

\begin{tabular}{|c|c|c|}
\hline $\begin{array}{l}\text { Reactor } \\
\text { Type } \\
\end{array}$ & $\begin{array}{c}\text { Commercialization } \\
\text { Availability } \\
\text { Date } \\
\end{array}$ & Fuel Cycle \\
\hline \multirow[t]{3}{*}{ LWR } & 1968 & Uranium \\
\hline & 1976 & Self-produced plutonium recycle \\
\hline & 1984 & Full plutonium recycle \\
\hline \multirow[t]{2}{*}{ LMFBR } & 1992 & Reference LMFBR (20 year doubling) \\
\hline & 1996 & Reference LMFBR (12 year doubling) \\
\hline \multirow[t]{5}{*}{ HTGR } & 1980 & $233 \mathrm{U}$ makeup without recycle \\
\hline & 1982 & ${ }^{233} \mathrm{U}$ makeup with full recycle \\
\hline & 1982 & 235 makeup with self-produced recycle \\
\hline & 1984 & Plutonium makeup \\
\hline & 1984 & Plutonium makeup with recycle \\
\hline
\end{tabular}

Constant 1974 dollars were used as the basis for this analysis. The capital costs were based on the latest 1974 costs reported to ERDA by the utilities for fossil and thermal reactors. (24) Capital costs for the LMFBR were assumed to be $\$ 100 / \mathrm{kW}$ higher than the LWR while the capital costs for the fusion power plant were selected so that the total power cost was approximately 3 to $10 \%$ less than the LMFBR. Fossil fuel costs were based on 1974 monthly summary reports. (25)

The present value of total system costs from 1974 to 2040 discounted to 1974 at $8.8 \%$ was calculated for each case and the results are shown in Table 11. The benefits of fusion power plants for the Forecast II electric energy use (ERDA, P\&A 1975 low forecast) are given by the difference in these present values of electricity production costs between Cases 2 and 5 , and Case 6 . Thus, the discounted benefits would be $\$ 5$ billion if the fusion power plant produces electricity at $10 \%$ less cost than the LMFBR or $\$ 2$ billion if it had a cost advantage of $3 \%$. 
TABLE 11. Total Estimated Present Value of Electricity Production Costs

Trillion $1974 \$$

Case Discounted at $8.8 \%$

1

2

3
1.181

0.740

0.434

$\begin{array}{cc}\text { Case } & \begin{array}{c}\text { Trillion } 1974 \$ \\ \text { Discounted at } 8.8 \%\end{array} \\ 4 & 0.267 \\ 5 & 0.737 \\ 6 & 0.742\end{array}$

The summaries of generating plants built in each decade by type are listed in Table 12 for Cases 1 through 6 ; the installed capacity by plant type is listed in Table 13 for Cases 1 through 6; and the electrical generation by plant type is listed in Table 14 for Cases 1 through 6 . Tables 12 through 14 represent thermal plants built after 1970. 01d fossil plants, hydroelectric, and internal combustion generators are excluded from the LP mode1. These generated an additional 482,000,000 MW-hr/yr in 1970, but will decline in importance as old plants are retired and replaced by new ones.

TABLE 12. Estimated Capacity Built (GWe) by Decade

\begin{tabular}{|c|c|c|c|c|c|c|}
\hline & $\begin{array}{l}\text { Light } \\
\text { Water } \\
\text { Redctor } \\
\text { (LWR) }\end{array}$ & $\begin{array}{l}\text { High } \\
\text { Tempera ture } \\
\text { Gas Reactor } \\
\text { (HTGR) }\end{array}$ & $\begin{array}{l}\text { Liquid Metal } \\
\text { Fast Breeder } \\
\text { Reactor } \\
\text { (LMFBR) } \\
\end{array}$ & $\begin{array}{l}\text { Fusion } \\
\text { Reactors }\end{array}$ & Fossil & Total \\
\hline $\begin{array}{l}1970-79 \\
1980-89 \\
1990=99 \\
2000-09 \\
2010-19 \\
2020=29 \\
2030-39\end{array}$ & $\begin{array}{r}71 \\
392 \\
506 \\
297 \\
301 \\
262 \\
221\end{array}$ & $\begin{array}{r}33 \\
90 \\
62 \\
496 \\
839 \\
138\end{array}$ & $\begin{array}{r}30 \\
662 \\
1017 \\
241 \\
48\end{array}$ & $\begin{array}{r}621 \\
2269 \\
5946\end{array}$ & $\begin{array}{l}233 \\
156 \\
247 \\
601 \\
877 \\
612 \\
630\end{array}$ & $\begin{array}{r}306 \\
581 \\
873 \\
1622 \\
2753 \\
4223 \\
6983\end{array}$ \\
\hline $\begin{array}{l}1970-79 \\
1980=89 \\
1990=99 \\
2000=09 \\
2010=19 \\
2020=29 \\
2030=39\end{array}$ & $\begin{array}{r}71 \\
280 \\
376 \\
247 \\
200 \\
201 \\
200\end{array}$ & $\begin{array}{r}32 \\
51 \\
100 \\
273 \\
305 \\
76\end{array}$ & $\begin{array}{r}31 \\
375 \\
493 \\
170 \\
47\end{array}$ & $\begin{array}{r}62 \\
835 \\
1910\end{array}$ & $\begin{array}{r}192 \\
99 \\
128 \\
221 \\
271 \\
251 \\
216\end{array}$ & $\begin{array}{r}263 \\
411 \\
586 \\
943 \\
1299 \\
1762 \\
2449\end{array}$ \\
\hline $\begin{array}{l}1970=79 \\
1980=89 \\
1990=99 \\
2000=09 \\
2010=19 \\
2020=29 \\
2030=39\end{array}$ & $\begin{array}{r}63 \\
148 \\
219 \\
121 \\
106 \\
108 \\
106\end{array}$ & $\begin{array}{r}33 \\
21 \\
43 \\
155 \\
136 \\
52 \\
38\end{array}$ & $\begin{array}{l}30^{.4} \\
144 \\
199 \\
82 \\
49\end{array}$ & $\begin{array}{r}62 \\
485 \\
753\end{array}$ & $\begin{array}{r}742 \\
75 \\
66 \\
700 \\
111 \\
79 \\
96\end{array}$ & $\begin{array}{l}205.3 \\
244.4 \\
358 \\
520 \\
614 \\
806 \\
1042\end{array}$ \\
\hline $\begin{array}{l}1970=79 \\
1980=89 \\
1990=99 \\
2000=09 \\
2010=19 \\
2020=29 \\
2030=39\end{array}$ & $\begin{array}{r}63 \\
125 \\
148 \\
96 \\
84 \\
85 \\
83\end{array}$ & $\begin{array}{l}14^{.33} \\
25 \\
91 \\
9 \\
5 \\
10\end{array}$ & $\begin{array}{l}.4 \\
5.6 \\
18 \\
83 \\
41 \\
11\end{array}$ & $\begin{array}{r}37 \\
135 \\
220\end{array}$ & $\begin{array}{r}111 \\
29 \\
34 \\
36 \\
36 \\
35 \\
22\end{array}$ & $\begin{array}{l}174.3 \\
168.4 \\
212.6 \\
241 \\
249 \\
301 \\
346\end{array}$ \\
\hline $\begin{array}{l}1970=79 \\
1980=89 \\
1990=99 \\
2000-09 \\
2010=19 \\
2020=29 \\
2030=39\end{array}$ & $\begin{array}{r}71 \\
282 \\
376 \\
252 \\
200 \\
201 \\
200\end{array}$ & $\begin{array}{r}32 \\
51 \\
98 \\
269 \\
310 \\
51\end{array}$ & $\begin{array}{r}31 \\
376 \\
493 \\
164 \\
47\end{array}$ & $\begin{array}{r}62 \\
835 \\
2010\end{array}$ & $\begin{array}{r}191 \\
97 \\
128 \\
218 \\
273 \\
252 \\
143\end{array}$ & $\begin{array}{r}262 \\
411 \\
586 \\
944 \\
1297 \\
1762 \\
2451\end{array}$ \\
\hline $\begin{array}{l}1970-79 \\
1980-89 \\
1990=99 \\
2000=09 \\
2010=19 \\
2020=29 \\
2030=39\end{array}$ & $\begin{array}{r}71 \\
282 \\
377 \\
254 \\
202 \\
202 \\
202\end{array}$ & $\begin{array}{l}32.33 \\
51 \\
55 \\
45 \\
317 \\
296\end{array}$ & $\begin{array}{c}30^{.4} \\
418 \\
787 \\
923 \\
1627\end{array}$ & & $\begin{array}{r}191 \\
97 \\
127 \\
217 \\
265 \\
318 \\
326\end{array}$ & $\begin{array}{l}262.3 \\
411.4 \\
585 \\
944 \\
1299 \\
1760 \\
2451\end{array}$ \\
\hline
\end{tabular}


TABLE 13. Estimated Installed Capacity (GWe) at Beginning of Year

\begin{tabular}{|c|c|c|c|c|c|c|}
\hline Year & $\begin{array}{c}\text { Light } \\
\text { water } \\
\text { Reactor } \\
\text { (LWR) } \\
\end{array}$ & $\begin{array}{c}\text { High } \\
\text { Temperature } \\
\text { Gas Reactor } \\
\text { (HTGR) } \\
\end{array}$ & $\begin{array}{l}\text { Liquid Metal } \\
\text { Fast Breeder } \\
\text { Reactor } \\
\text { (LMFBR) } \\
\end{array}$ & $\begin{array}{c}\begin{array}{c}\text { Fusion } \\
\text { Reactors } \\
\end{array} \\
\end{array}$ & Fossil & Total \\
\hline 1980 & 74 & .33 & & & 387 & 461.3 \\
\hline 1990 & 426 & 33 & .4 & & 454 & 913.4 \\
\hline 2000 & 929 & 123 & 30 & & 636 & 1718 \\
\hline 2010 & 1195 & 185 & 692 & & 1004 & 3076 \\
\hline 2020 & 1104 & 648 & 1709 & 62 & 1725 & 5247 \\
\hline 2030 & 860 & 1397 & 1920 & 2331 & 2090 & 8598 \\
\hline 2040 & 784 & 1473 & 1306 & 8277 & 2119 & 13959 \\
\hline 1980 & 74 & .33 & & & 345 & 419.3 \\
\hline 1990 & 354 & 32 & .4 & & 355 & 741.4 \\
\hline 2000 & 727 & 83 & 31 & & 418 & 1259 \\
\hline 2010 & 903 & 183 & 406 & & 448 & 1940 \\
\hline 2020 & 823 & 424 & 899 & 62 & 620 & 2828 \\
\hline 2030 & 648 & 678 & 1038 & 897 & 743 & 4004 \\
\hline 2040 & & 654 & 710 & 2807 & 738 & \\
\hline 1980 & 65 & .33 & & & 296 & 362.3 \\
\hline 1990 & 214 & 21 & .4 & & 282 & 517.4 \\
\hline 2000 & 430 & 64 & 30 & & 283 & 807 \\
\hline 2010 & 488 & 219 & 174 & & 241 & 1122 \\
\hline 2020 & 446 & 334 & 373 & 62 & 277 & 1492 \\
\hline 2030 & 335 & 343 & 425 & 547 & 290 & 1940 \\
\hline 2040 & 320 & 226 & 330 & 1300 & 286 & 2462 \\
\hline 1980 & 66 & .33 & & & 265 & 331 \\
\hline 1990 & 191 & 14 & .4 & & 205 & 411 \\
\hline 2000 & 336 & 39 & $6^{-4}$ & & 174 & 555 \\
\hline 2010 & 369 & 130 & 24 & & 99 & 622 \\
\hline 2020 & 328 & 125 & 107 & 37 & 106 & 703 \\
\hline 2030 & 265 & 105 & 142 & 172 & 107 & 791 \\
\hline 2040 & 252 & 24 & 135 & 392 & 93 & 896 \\
\hline & 74 & .33 & & & 345 & \\
\hline 1990 & 356 & 32 & .4 & & 353 & 741.4 \\
\hline 2000 & 729 & 83 & 31 & & 416 & 1259 \\
\hline 2010 & 910 & 181 & 407 & & 443 & 1940 \\
\hline 2020 & 828 & 418 & 900 & 62 & 679 & 2828 \\
\hline 2030 & 653 & 677 & 1033 & 897 & 743 & 4003 \\
\hline & 601 & 630 & 704 & 2907 & 668 & 5510 \\
\hline & 74 & .33 & & & 345 & 419.3 \\
\hline & 356 & 32 & .4 & & 353 & 741.4 \\
\hline 200 & 730 & 83 & $30^{4}$ & & 415 & 1258 \\
\hline 201 & 913 & 138 & 448 & & 441 & 1940 \\
\hline 202 & 833 & 151 & 1235 & & 609 & 2828 \\
\hline 2030 & 658 & 417 & 2128 & & 800 & 4003 \\
\hline 2040 & 606 & 658 & 3337 & & 909 & 5510 \\
\hline
\end{tabular}

TABLE 14. Estimated Annual Electric Generation by Plant Type

\begin{tabular}{|c|c|c|c|c|c|c|}
\hline & $\begin{array}{l}\text { Light } \\
\text { Water } \\
\text { Reactor } \\
\text { (LWR) } \\
\end{array}$ & $\begin{array}{l}\text { High } \\
\text { Temperature } \\
\text { GaS Reactor } \\
\text { (HTGR) } \\
\end{array}$ & $\begin{array}{l}\text { (Trillion Wat } \\
\text { Liquid Metal } \\
\text { Fast \&reeder } \\
\text { Reactor } \\
\text { (LMFBR) } \\
\end{array}$ & $\begin{array}{c}\text { Fusion } \\
\text { Reactors }\end{array}$ & Fossil & Total \\
\hline $\begin{array}{l}1980 \\
1990 \\
2000 \\
2010 \\
2020 \\
2030 \\
2040\end{array}$ & $\begin{array}{r}432 \\
2310 \\
4862 \\
5489 \\
4435 \\
3307 \\
3138\end{array}$ & $\begin{array}{r}2 \\
225 \\
760 \\
956 \\
3050 \\
6556 \\
6217\end{array}$ & $\begin{array}{r}3 \\
289 \\
4464 \\
10416 \\
10275 \\
6037\end{array}$ & $\begin{array}{r}565 \\
14689 \\
44166\end{array}$ & $\begin{array}{l}1822 \\
2222 \\
2248 \\
4854 \\
8505 \\
9640 \\
9036\end{array}$ & $\begin{array}{r}2256 \\
4760 \\
8859 \\
15763 \\
26971 \\
44467 \\
68594\end{array}$ \\
\hline $\begin{array}{l}1980 \\
1990 \\
2000 \\
2010 \\
2020 \\
2030 \\
2040\end{array}$ & $\begin{array}{l}425 \\
1880 \\
3731 \\
4082 \\
3313 \\
2506 \\
2407\end{array}$ & $\begin{array}{r}21 \\
210 \\
540 \\
988 \\
2082 \\
3063 \\
2546\end{array}$ & $\begin{array}{r}3 \\
249 \\
2674 \\
5576 \\
5626 \\
3387\end{array}$ & $\begin{array}{r}460 \\
5840 \\
15456\end{array}$ & $\begin{array}{l}1585 \\
1697 \\
1860 \\
2117 \\
3000 \\
3511 \\
3304\end{array}$ & $\begin{array}{r}2012 \\
3790 \\
6380 \\
9861 \\
14451 \\
20546 \\
27200\end{array}$ \\
\hline $\begin{array}{l}1980 \\
1990 \\
2000 \\
2010 \\
2020 \\
2030 \\
2040\end{array}$ & $\begin{array}{r}377 \\
1260 \\
2288 \\
2341 \\
1858 \\
1398 \\
1374\end{array}$ & $\begin{array}{r}2 \\
144 \\
439 \\
1137 \\
1588 \\
1356 \\
940\end{array}$ & $\begin{array}{r}3 \\
216 \\
1177 \\
2378 \\
2388 \\
1633\end{array}$ & $\begin{array}{r}476 \\
3517 \\
7173\end{array}$ & $\begin{array}{l}1318 \\
1330 \\
1335 \\
1109 \\
1386 \\
1365^{\circ} \\
1286\end{array}$ & $\begin{array}{l}1697 \\
2737 \\
4178 \\
5764 \\
7686 \\
10024 \\
12372\end{array}$ \\
\hline $\begin{array}{l}1980 \\
1990 \\
2000 \\
2010 \\
2020 \\
2030 \\
2040\end{array}$ & $\begin{array}{r}396 \\
1138 \\
1836 \\
1861 \\
1505 \\
1206 \\
1133\end{array}$ & $\begin{array}{r}2 \\
95 \\
279 \\
816 \\
733 \\
477 \\
133\end{array}$ & $\begin{array}{r}3 \\
38 \\
173 \\
704 \\
872 \\
719\end{array}$ & $\begin{array}{l}250 \\
561 \\
474\end{array}$ & $\begin{array}{r}1175 \\
931 \\
728 \\
483 \\
565 \\
1152 \\
2381\end{array}$ & $\begin{array}{l}1573 \\
2167 \\
2881 \\
3333 \\
3357 \\
4270 \\
4840\end{array}$ \\
\hline $\begin{array}{l}1980 \\
1990 \\
2000 \\
2010 \\
2020 \\
2030 \\
2040\end{array}$ & $\begin{array}{r}425 \\
1892 \\
3742 \\
4107 \\
3334 \\
2520 \\
2409\end{array}$ & $\begin{array}{r}2 \\
210 \\
541 \\
972 \\
2018 \\
3060 \\
2548\end{array}$ & $\begin{array}{r}3 \\
249 \\
2675 \\
5579 \\
5590 \\
2248\end{array}$ & $\begin{array}{r}460 \\
5860 \\
15908\end{array}$ & $\begin{array}{l}1585 \\
1685 \\
1848 \\
2097 \\
3058 \\
3514 \\
2987\end{array}$ & $\begin{array}{r}2012 \\
3790 \\
6380 \\
9861 \\
7448 \\
20544 \\
27200\end{array}$ \\
\hline $\begin{array}{l}1980 \\
1990 \\
2000 \\
2010 \\
2020 \\
2030 \\
2040\end{array}$ & $\begin{array}{r}426 \\
1892 \\
3745 \\
4125 \\
3357 \\
2542 \\
2427\end{array}$ & $\begin{array}{r}2 \\
210 \\
548 \\
784 \\
738 \\
1904 \\
2935\end{array}$ & $\begin{array}{r}3 \\
242 \\
2854 \\
7377 \\
12260 \\
17589\end{array}$ & & $\begin{array}{l}1586 \\
.1685 \\
1845 \\
2089 \\
2996 \\
3849 \\
4271\end{array}$ & $\begin{array}{r}2014 \\
3790 \\
6380 \\
9852 \\
14688 \\
20555 \\
27222\end{array}$ \\
\hline
\end{tabular}




\section{ESTIMATED TOTAL MATERIAL USAGE (WITH AND WITHOUT FUSION POWER PLANTS)}

To determine the impact of fusion power plant construction on materials availability, the quantity of materials that would be used if fusion power plants were not built was first estimated. Since the demand for most materials is derived from their use in another product, the final demand must be established for all commodities that use these materials in their production. (Final demand as used here and in all input/output analysis refers to the sales of products for final consumption and does not include inter-industry sales of commodities.) To accomplish this the EXPLOR MULTITRADE, an econometric model that embodies a comprehensive input/output analysis system, was used. EXPLOR MULTITRADE calculates the total output of all commodities necessary to produce the projected final demand; a brief description of the code and input data is presented in Appendix $A$.

For the purpose of this study, materials "critical" to the fusion power plant construction were assumed to be those where construction of 25 fusion power plants/year would require more than $1 \%$ of the present U.S. consumption of that material or where domestic reserves were considered to be very small compared to current use rates. Many basic materials are included in all EXPLOR MULTITRADE analyses. Table 15 shows the typical materials used in fusion power plant construction and the estimated quantities of each used per Me of capacity built. These estimates were taken from the design that is expected to use the largest quantities (UWMAK-I or PPPL).

TABLE 15. Estimated Critical Material Usage for Constructing a Hypothetical Fusion Power Plant

\begin{tabular}{|c|c|c|c|}
\hline Material & $\begin{array}{c}\text { Usage, }(\mathrm{a}) \\
\text { Metric Ton/MNe } \\
\end{array}$ & Material & $\begin{array}{c}\text { Usage, }(a) \\
\text { Metric Ton/MWe }\end{array}$ \\
\hline Aluminum & 0.54 & Manganese & 0.82 \\
\hline Beryllium & 0.43 & Molybdenum & 0.41 \\
\hline Boron & 1.07 & Niobium & 0.09 \\
\hline Chromium & 7.92 & Nickel & 5.9 \\
\hline Copper & 7.27 & Lead & 13.9 \\
\hline Iron & 77.80 & Sodium & 12.1 \\
\hline Helium & 0.09 & Tin & 0.02 \\
\hline Mercury & 0.002 & Titanium & 0.05 \\
\hline Lithium & 1.15 & Zirconium & 0.07 \\
\hline
\end{tabular}

(a) The quantities were taken from the conceptual designs that are expected to use the largest amounts of materials (UWMAK-I or PPPL)

To determine domestic use of materials assuming no fusion power plants are built, but that the same electrical generation is produced by other nuclear plants, EXPLOR MULTITRADE computer runs were made for the years 2010, 2020, and 2040; projected domestic use of these materials for these years as well as for 1973 is shown in Table 16. The numbers represent order-of-magnitude estimates. The values in Table 16 were derived by assuming an overall GNP growth rate of approximately 3\% between now and 2010, and a growth rate of approximately $2 \%$ thereafter. Total electricity consumption is assumed to be the same as that listed for Case II on Table 14. 
TABLE 16. Estimated Domestic Annual Use of Critical Materials Assuming No Fusion Power Plants

\begin{tabular}{|c|c|c|c|c|}
\hline & \multicolumn{4}{|c|}{ Metric Tons Used } \\
\hline & 1973 & 2010 & 2020 & 2040 \\
\hline Beryllium & 383 & 4,960 & 6,000 & 9,170 \\
\hline Chromium & 656,000 & $2,120,000$ & $2,604,000$ & $4,100,000$ \\
\hline Copper & $1,942,000$ & $5,940,000$ & $7,790,000$ & $12,418,000$ \\
\hline Iron Ore & $92,500,000$ & $376,000,000$ & $474,000,000$ & $737,600,000$ \\
\hline Helium & 2,500 & 10,800 & 14,500 & 22,900 \\
\hline Mercury & 1,850 & 8,200 & 10,400 & 15,900 \\
\hline Lithium & 3,600 & 11,700 & 15,400 & 23,700 \\
\hline Molybdenum & 33,100 & 82,020 & 108,800 & 169,000 \\
\hline Nickel & 285,000 & 798,000 & 989,000 & $1,543,000$ \\
\hline Lead & $1,758,000$ & $10,357,000$ & $13,436,000$ & $21,297,000$ \\
\hline
\end{tabular}

Table 17 lists projected domestic usage for these same critical materials for the years 2010, 2020, and 2040 assuming introduction of fusion power plants at the rate shown in Case II above. Although only the first fusion power plant would be scheduled to be on 1 ine in 2010 , more plants would be under construction at that time. Therefore, the figures in Table 17 include materials used not only for plants completed in the indicated year, but also for construction of plants to be completed later.

The actual projection of fusion power plant growth was done in a linear programming model ${ }^{(23)}$ which minimized the discounted cost of building and operating thermal power plants subject to many decision limiting constraints as described in the previous section.

TABLE 17. Estimated Domestic Annual Use of Critical Materials Assuming Introduction of Fusion Power Plants

\begin{tabular}{|c|c|c|c|c|c|c|}
\hline Material & $\begin{array}{l}\text { Metric Tons } \\
\text { in } 2010 \\
\end{array}$ & $\begin{array}{c}\text { \% Change from } \\
\text { non-Fus ion } \\
\text { Reactor Case } \\
\end{array}$ & $\begin{array}{l}\text { Metric Tons } \\
\text { in } 2020 \\
\end{array}$ & $\begin{array}{c}\text { Change from } \\
\text { non-Fusion } \\
\text { Reactor Case }\end{array}$ & $\begin{array}{l}\text { Metric Tons } \\
\text { in } 2040 \\
\end{array}$ & $\begin{array}{l}\text { \% Change from } \\
\text { non-Fusion } \\
\text { Reactor Case }\end{array}$ \\
\hline Beryllium & 9,730 & 100.3 & 52,167 & 769 & 142,000 & 1,449 \\
\hline Chromium & $2,207,000$ & 4.2 & $3,450,000$ & 32 & $6,540,000$ & 60 \\
\hline Copper & $6,080,000$ & 2.4 & $8,230,000$ & 6 & $13,700,000$ & 10 \\
\hline Iron Ore & $381,000,000$ & 1.3 & $478,000,000$ & 0.8 & $741,000,000$ & 0.5 \\
\hline Helium & 11,600 & 9.7 & 24,100 & 71 & 51,000 & 129 \\
\hline Mercury & 8,300 & 0.2 & 10,700 & 3 & 16,400 & 3.2 \\
\hline Lithium & 23,195 & 98 & 127,000 & 725 & 345,000 & 1,356 \\
\hline Molybdenum & 86,600 & 5.6 & 152,000 & 40 & 295,000 & 75 \\
\hline Nickel & 863,000 & 8.2 & $1,620,000$ & 64 & $3,369,000$ & 118 \\
\hline Lead & $10,500,000$ & 1.5 & $14,900,000$ & 11 & $25,500,000$ & 20 \\
\hline
\end{tabular}


The materials use estimates in Tables 16 and 17 were summed for the period 1975 through 2040. The values for the intervening years were determined by interpolating between years that are shown. The total estimated domestic use of these materials between 1975 and 2040 appears in Table 18.

TABLE 18. Total Estimated Domestic Cumulative Use of Critical Materials (1975-2040)

\begin{tabular}{|c|c|c|}
\hline \multirow[b]{2}{*}{ Material } & \multicolumn{2}{|c|}{$\begin{array}{c}\text { Mi11ions of Metric } \\
\text { Tons Used }\end{array}$} \\
\hline & $\begin{array}{c}\text { With } \\
\text { Fusion } \\
\text { Reactors } \\
\end{array}$ & $\begin{array}{l}\text { Without } \\
\text { Fusion } \\
\text { Reactors }\end{array}$ \\
\hline Beryllium & 2.436 & 0.304 \\
\hline Chromi um & 181 & 141 \\
\hline Copper & 439 & 412 \\
\hline Iron Ore & 25000 & 25000 \\
\hline Helium & 1.2 & 0.73 \\
\hline Mercury & 54 & 54 \\
\hline Lithium & 5.965 & 0.809 \\
\hline Molybdenum & 8 & 6 \\
\hline Nickel & 83 & 54 \\
\hline Lead & 757 & 686 \\
\hline
\end{tabular}




\section{THE MEANING OF "AVAILABILITY"}

In assessing future materials availability one must first establish what is meant by the term "availability". First it should be noted that we are talking about the supply of these materials in the future. In economics, the supply of a commodity in a given time period is described by a price versus quantity relationship. Producers are willing to supply more of a commodity if they are offered a higher price. This is so because in the short run, production costs increase as output per unit time increases beyond nomal operating levels of any fixed capacity. In the long run this capacity can be expanded. The prime cause of increasing supply prices of minerals over time is the mining of more accessible, higher grade ores first. We will return to this point in discussing the concept of "reserves". For now the important point is that the amount of a material that producers will supply is an increasing function of the price of this material.

Thus when people speak of a material being "available" the economist always asks "at what price?". The usual answer to this is "at a 'reasonable' price". This usually means that the price is not so much higher than present levels relative to other goods and services and people's incomes (in the case of final consumers) or revenues (in the case of an intermediate producer) that "many" people will reduce their purchases of this or items "very much" below what they would have bought at a lower or "more reasonable" price. Several points follow from this discussion:

1) People are willing to buy more of a commodity the lower its price compared to other goods and services. This inverse relationship between price and quantity is called a demand curve for the commodity.

2) People will buy more of a commodity if their incomes or revenues are higher and nothing else changes. Economists depict this as an upward shift in the demand curve.

3) When people speak of the future availability of an item they are really talking about how high its price is expected to be.

4) An interaction of supply and demand in markets for these items determines how high their prices are (in the absence of government controls).

5) This supply and demand interaction determines material use levels as well as their prices. We have already discussed expected material use levels, so all that remains to be discussed

is (A) whether these prices will increase enough as a result of the use of these materials for other purposes that these materials become "too expensive" relative to their substitutes to use them in fusion power plants and (B) whether the associated prices of these materials are expected to increase significantly as a result of the use of these materials in fusion power plants. If the answer to (A) is "no" then these materials will be judged as being "available" for use in fusion power plants. If the answer to $(B)$ is "no" then the "availability" of these materials will be judged as being unaffected by the use of these materials in fusion power plants. It 
should be clear that the answers to these two questions may be different depending on who answers them. The answers given here are those of the authors, but it is our view that most experts in the area of materials availability would agree with them.

This section of the report provides a preliminary assessment of the availability of raw materials which would ultimately be used in fusion power plants. These materials must go through several production stages before they are in the form to be used in fusion power plants. This report does not address productive capacity in these refining, manufacturing, and fabrication industries, because their capacity can be expanded if there is sufficient demand for their products and lead time. An assessment of manufacturing and fabrication technology can be found in Reference 26.

The availability of critical materials for fusion power plant construction was examined by reviewing U.S. and World reserves and resources, and comparing the quantities of materials expected to be used in the future with and without fusion power plants to these reserves and resources.

\section{RESERVES AND RESOURCES}

Reliability of the information on mineral resources is impaired by the inconsistent use of the terms "reserves" and "resources". These terms have significantly different meanings and connotations, but are sometimes used interchangeably. Reserves and resources as used in this report are defined as follows: 1) Reserves are the quantities of ore minerals located in identified deposits that can be developed profitably at current prices using current technology. Thus, they are dynamic and constantly changing as mineral prices and extraction technology change. Reserves are a function of man, as well as nature, and form the basis for the material supply system. 2) Resources are static since they are limited by the composition of the earth's crust, seas and atmosphere. Resources include undiscovered mineral deposits and reserves as well as identified mineral deposits that cannot be profitably recovered at current prices using current technology. Resource estimates based on the average crustal concentration (crustal abundance) are the maximum expected. Some resources can become reserves with higher prices or with the implementation of new technology.

Thus, reserves, which are identified by physically sampling the ore body, are constantly changing and usually increasing through price changes, discovery of new mineral deposits and the development of new technology. Projections of future reserves can be made using estimates or assumptions regarding future demands for these materials, technological change, and discovery rates. These future reserve estimates require assessment of the relative cost of extracting resources which are not yet discovered. As a result, good estimates are expensive and are not generally available.

Based on estimates of world resources and crustal abundance there are probably ample resources of minerals in the earth's crust which are expected to become reserves fast enough to allow use patterns of these materials to continue largely along present trends without significant relative price increases. Many areas of the world are only now being explored for 
minerals and vast untapped resources are expected to exist in these areas. In addition, the mineral resources of the oceans which are close to being reserves are considerable, particularly for nickel, copper, manganese, and cobalt contained in nodules on the ocean floor.

Introductory chapters in USGS Professional Paper $820^{(27)}$ provide some excellent discussion on the classification of resources as well as a comprehensive treatise on mineral resources. The U.S. Bureau of Mines, Commodity Data Summaries, ${ }^{(28)}$ was also examined for this report as well as Mineral Yearbooks, (29) a survey of selected material resources by Prof. Cameron ${ }^{(31)}$ and this USGS Professional Paper. (27)

Any attempt to assess the distant-future availability of materials using currently estimated reserves is fraught with risk. Resources are usually developed into reserves only to the extent that near-term exploitation of them seems likely. To do otherwise would entail premature exploration and development expenses. As a consequence, estimates of reserves are similar to inventories in other businesses; they do not necessarily decline over time in spite of sustained use of these reserves. World reserves of many minerals have actually grown at a rapid rate in the recent past (Table 19). For example, in 1950, world reserves of copper were 100 million metric tons while in 1970 they were 279 million metric tons. This represents a percentage increase of $179 \%$. Even larger percentage increases in reserves have occurred. Since 1950 the reserves of phosphates have increased by $4430 \%$. Nevertheless, estimates of reserves are used in the present analysis to infer where shortages, which cause price increases, might be expected for elements expected to be used in the construction of fusion power plants.

\begin{tabular}{|c|c|c|c|}
\hline Ore & $\begin{array}{c}\text { Reserves }-1950 \\
(1,000 \\
\text { Metric Tons) } \\
\end{array}$ & $\begin{array}{c}\text { Reserves }-1970 \\
(1,000 \\
\text { Metric Tons) }\end{array}$ & $\begin{array}{c}\% \\
\text { Increase }\end{array}$ \\
\hline Iron & $19,000,000$ & $251,000,000$ & 1,321 \\
\hline Manganese & 500,000 & 635,000 & 27 \\
\hline Chromite & 100,000 & 775,000 & 675 \\
\hline Tungsten & 1,903 & 1,328 & -30 \\
\hline Copper & 100,000 & 279,000 & 179 \\
\hline Lead & 40,000 & 86,000 & 115 \\
\hline Zinc & 70,000 & 113,000 & 61 \\
\hline Tin & 6,000 & 6,600 & 10 \\
\hline Bauxite & $1,400,000$ & $5,300,000$ & 279 \\
\hline Potash & $5,000,000$ & $118,000,000$ & 2,360 \\
\hline Phosphates & $26,000,000$ & $1,178,000,000$ & 4,430 \\
\hline $0 i 1$ & $75,000,000$ & $455,000,000$ & 507 \\
\hline
\end{tabular}

(a) Source: Council on International Economic Policy, Executive Office of the President, Special Report, Critical Imported Materials (Washington, D.C.: U.S. Government Printing Office, December 1974). (3T) 
COMPARING MATERIALS USES TO RESERVES AND RESOURCES

The effect of fusion power plant construction on the projected availability of materials was determined by comparing the quantities of these materials expected to be used in the future to current estimate of U.S. and world reserves and resources; U.S. and world reserves of materials expected to be used in fusion power plant construction are presented in Table 20. Table 21 compares cumulative use with and without fusion power plant uses to U.S. and world reserves and resources for select elements. It is apparent from this comparison that if one were to look only at current U.S. reserves defined by present technology costs and prices, seven of the fusion power plant materials might be expected to become very expensive before 2010 as they become more scarce: beryllium, chromium, copper, iron, mercury, nickel and lead (Table 22). However, resources of these "critical" materials, although finite, are extremely large compared to reserves. Fusion power plant materials demands per se are not expected to contribute appreciably to these higher prices and hence to lack of "availability" except for beryllium and nickel where the change in consumption is expected to increase nearly $100 \%$ as a result of their use in fusion power plants.

TABLE 20. U.S. and World Resources, Crustal Abundance, 1974 Reserves, 1974 Production and 1974 Consumption for Fusion Power Plant Construction Materials

\begin{tabular}{|c|c|c|c|c|c|c|c|c|c|}
\hline \multirow[b]{3}{*}{ Materia 1} & \multicolumn{9}{|c|}{ Million Metric Tons of Metal } \\
\hline & \multicolumn{2}{|c|}{$\begin{array}{c}1974 \\
\text { Reserves (a) }\end{array}$} & \multicolumn{2}{|c|}{$\begin{array}{l}\text { Estima ted } \\
\text { Resources (b) }\end{array}$} & \multirow{2}{*}{$\begin{array}{l}\text { Recoverabie } \\
\text { on Crustal } \\
\text { U.S. }\end{array}$} & $\begin{array}{l}\text { Resources Based } \\
\text { Abundance (c,d) }\end{array}$ & \multicolumn{2}{|c|}{$\begin{array}{c}1974 \\
\text { Production (a) }\end{array}$} & \multirow{2}{*}{$\begin{array}{l}1974 \text { U.S. } \\
\text { Consumption }\end{array}$} \\
\hline & U.S. & World & U.S. & World & & Horld & U.S. & World & \\
\hline Aluminum & 6.1 & 2,400 & $>1,000$ & $>28,000$ & 203,000 & $3,520,000$ & 4.4 & 12.8 & 4.9 \\
\hline Beryllium & 0.025 & 0.05 & $>0.3$ & $>0.7$ & 1.1 & 19 & NA. & 0.00016 & - \\
\hline Boron & 28 & 66 & 100 & NA & - & - & 1.1 & 2.1 & 0.2 \\
\hline Chromium & 0.0 & 460 & $>1.0$ & $>1,000$ & 189 & 3,300 & 0.0 & 2.0 & 0.5 \\
\hline Copper & 82 & 390 & 160 & 680 & 122 & 2,100 & 1.5 & 7.2 & 1.8 \\
\hline Hel ium & 0.78 & NA & 4.7 & NA & - & - & 0.0043 & 0.005 & - \\
\hline Iron & 1,800 & 88,000 & $>30,000$ & $>230,000$ & 118,000 & $2,030,000$ & 76 & 800 & 91 \\
\hline Lead & 38 & 140 & $>50$ & $>500$ & 32 & 550 & 0.62 & 3.4 & 0.8 \\
\hline Lithium & 0.36 & 1.1 & $>5.7$ & 9.1 & 54 & 930 & $w 0.002$ & 20.003 & $<0.003$ \\
\hline Manganese & 0.0 & 5,500 & 340 & 5,600 & 2,450 & 42,000 & 0.0 & 23 & 0.8 \\
\hline Mercury & 0.014 & 0.16 & $>0.1$ & $>1.0$ & 0.2 & 3.4 & 0.000051 & 0.0079 & - \\
\hline Molybdenum & 3.6 & 5.0 & 500 & $>1,000$ & 2.7 & 47 & 0.0052 & 0.0073 & 0.03 \\
\hline Nickel & 0.2 & 44 & 13 & 75 & 150 & 2,600 & 0.015 & 0.69 & 0.2 \\
\hline Niobium (Colombium) & 0.01 & 7.7 & $>0.1$ & 18 & 49 & 850 . & 0.0 & 0.011 & 0.001 \\
\hline Potassium & 230 & 67,000 & NA & $>100,000$ & - & - & 1.9 & 20.2 & - \\
\hline Sodium & 200 & 24,000 & NA & Very large & - & - & $>17$ & $>60$ & - \\
\hline $\operatorname{Tin}$ & 0.035 & 9.1 & 0.2 & 34 & 3.9 & 68 & 0.0 & 0.21 & - \\
\hline Titanium & $<0.2$ & $<6$ & 380 & $<90,000$ & 13.000 & 225,000 & $<0.016$ & $<0.051$ & $w .2$ \\
\hline Yttrium & 0.0008 & 0.033 & 80 & 14,000 & - & - & NA & $>0.0002$ & - \\
\hline Zirconium & 5.5 & NA & 5 & 20 & - & - & $<0.054$ & $<0.35$ & - \\
\hline
\end{tabular}

NA = Not available

(a) = Data are from Reference 28: USBM Commodity Data Sumaries, 1975.

(b) = Estimates derived from data in USGS Professional Paper 820, 1973. (27)

(c) = Data from Table 3, R. L. Erickson, Crustal Abundance of Elements, and Mineral Reserves and Resources in USGS PP820, pp. 22-23.(27)

(d) = These estimates used to calculate resources are based upon currently recoverable resources and do not include resources whose feasibility of economic recovery is not established. 
TABLE 21. Critical Fusion Power Plant Materials Uses Versus Current Reserves and Resources

\begin{tabular}{|c|c|c|c|c|c|c|c|c|c|c|}
\hline \multirow[b]{3}{*}{ Material } & \multirow{2}{*}{\multicolumn{2}{|c|}{$\begin{array}{l}\text { Total U.S. Use to } 2040 \text {, } \\
\text { Milition Metric Tons }\end{array}$}} & \multicolumn{4}{|c|}{$\begin{array}{c}\text { Ratio Cumulative Use }(1975-2040) \\
\text { to } 1974 \text { Reserves }\end{array}$} & \multirow{2}{*}{\multicolumn{4}{|c|}{$\frac{\text { Rat10 Cumulative Use }(1975-2040)}{\text { U.S. }}$ to Resources }} \\
\hline & & & \multicolumn{2}{|c|}{ U.S. } & \multicolumn{2}{|c|}{ World } & & & & \\
\hline & $\begin{array}{l}\text { Without } \\
\text { Fusion } \\
\text { Reactors }\end{array}$ & $\begin{array}{c}\text { With } \\
\text { Fuston } \\
\text { Reactors } \\
\end{array}$ & $\begin{array}{l}\text { Without } \\
\text { Fuston } \\
\text { Reactors }\end{array}$ & $\begin{array}{c}\text { W1th } \\
\text { Fusion } \\
\text { Reactors } \\
\end{array}$ & $\begin{array}{l}\text { Wi thout } \\
\text { Fusion } \\
\text { Reactors }\end{array}$ & $\begin{array}{c}\text { With } \\
\text { Fusion } \\
\text { Reactors } \\
\end{array}$ & $\begin{array}{l}\text { Without } \\
\text { Fusion } \\
\text { Reactors }\end{array}$ & $\begin{array}{c}\text { With } \\
\text { Fusion } \\
\text { Reactors } \\
\end{array}$ & $\begin{array}{l}\text { Without } \\
\text { Fuston } \\
\text { Reactors } \\
\end{array}$ & $\begin{array}{c}\text { With } \\
\text { Fusion } \\
\text { Reactors }\end{array}$ \\
\hline Beryl1 fum & 0.30 & 2.4 & 12 & 97 & NA & NA & 1.0 & 8.1 & 0.43 & $<3.5$ \\
\hline Chrom lum & 140 & 180 & -- & -- & 0.31 & 0.39 & 141 & 181 & 0.141 & 0.439 \\
\hline Copper & 410 & 440 & 5.0 & 5.4 & 1.1 & 1.1 & 2.6 & 2.7 & 0.61 & 0.66 \\
\hline Iron & 25000 & 25000 & 14 & 14 & 0.28 & 0.28 & 0.83 & 0.83 & 0.11 & 0.11 \\
\hline Helfum & 0.73 & 1.2 & 0.94 & 1.5 & NA & NA & 0.16 & 0.26 & NA & NA \\
\hline Mercury & 0.48 & 0.48 & 34 & 34 & 3.0 & 3.0 & $>4.8$ & $>4.8$ & $>0.48$ & $>0.48$ \\
\hline Ltthium & 0.81 & 6.0 & 0.89 & 6.6 & 0.74 & 5.5 & 0.14 & 1.1 & 0.09 & 0.66 \\
\hline Molybdenum & 6.0 & 8.0 & 1.7 & 2.2 & 1.2 & 1.6 & 0.01 & 0.016 & 0.006 & 0.008 \\
\hline Nickel & 54 & 83 & 270 & 415 & 1.2 & 1.9 & 4.2 & 6.4 & 0.73 & 1.1 \\
\hline Lead & 690 & 760 & 18 & 42 & 4.9 & 5.4 & 13.7 & 55.3 & 0.49 & $<1.5$ \\
\hline
\end{tabular}

TABLE 22. Dates of Depletion of 1974 U.S. Reserves of "Critical" Fusion Power Plant Materials, Assuming No Additions to Reserves

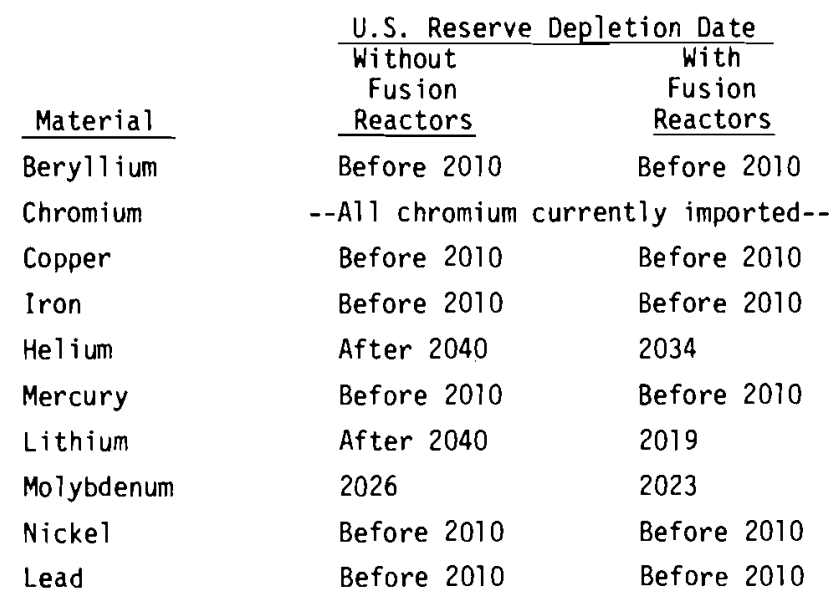

Table 23 presents the 1975 ratio of cutoff grade (lowest concentration profitably recoverable) to crustal abundance for several fusion reactor critical materials. The smaller this ratio the greater the expected chances that resources will continue to replenish reserves of this material as they are used. These data illustrate the range between concentrations of currently profitably mineable ore and crustal abundance. For example, the ratio of profitably mineable concentrations to crustal abundance of mercury is 11,200 while that for aluminum is only 2.2. This means that aluminum-bearing ore being mined today contains only 2.2 times more aluminum than the average concentration in the earth's crust, while mercury ore contains 11,200 times more mercury than crustal concentrations. 
TABLE 23. Ratio of 1975 Cutoff Grade to Crustal Abundance for Selected Minerals

\begin{tabular}{|c|c|c|c|}
\hline Element & $\begin{array}{c}\text { Crusta }{ }^{(a)} \\
\text { Abundance, } \\
\text { g/metric tons } \\
\end{array}$ & $\begin{array}{c}1975 \\
\text { Cutoff }(b) \\
\text { Grade, } \\
\text { g/metric } \\
\text { tons } \\
\end{array}$ & $\begin{array}{c}\text { Ratio: } \\
\text { (Cutoff Grade/ } \\
\text { Crustal Abundance) }\end{array}$ \\
\hline Mercury & 0.089 & 1,000 & 11,200 \\
\hline Tungsten & 1.1 & 4.500 & 4,000 \\
\hline Lead & 12 & 40,000 & 3,300 \\
\hline Chromfum & 110 & 230,000 & 2,100 \\
\hline Molybdenum & 1.3 & 2,000 & 1,540 \\
\hline $\operatorname{zinc}$ & 94 & 35,000 & 370 \\
\hline Lithium & 21 & 5,000 & 240 \\
\hline Beryllium & 1.3 & 200 & 154 \\
\hline Nickel & 89 & 9,000 & 100 \\
\hline Copper & 63 & 3,500 & 56 \\
\hline I ron & 58,000 & 200,000 & 3.4 \\
\hline A) luminum & 83,000 & 185,000 & 2.2 \\
\hline
\end{tabular}

(a) Tan Lee and Chi Lung Yao, Abundance of Chemical Elements in the Earths Crust and Its Major Tectonic Units: International Geology Review, Vol. 12, No. 7. 1970 p. $776-788 .(32)$

(b) The lowest concentration profitably recoverable in 1975.

\section{CRITICAL MATERIALS FOR FUSION POWER PLANT CONSTRUCTION}

This section summarizes the potential "availability" of critical fusion power plant construction materials (Table 24). As seen in this table, world resources are greater than expected U.S. cumulative use to 2040, while U.S. resources are less than expected U.S. cumulative use to 2040 for six out of the ten materials presented: beryllium, chromium, lead, 1ithium, mercury, and nickel. U.S. resources of copper, iron and molybdenum are expected to be greater than U.S. cumulative uses to 2040. Data on helium is insufficient to project availability.

TABLE 24. Summary of Material Availability for Select Fusion Power Plant Materials

\begin{tabular}{|c|c|c|c|}
\hline Material & $\begin{array}{l}\text { Projected } \\
\text { Production } \\
\text { Capacity (a) } \\
\end{array}$ & $\begin{array}{l}\text { Reserve and Resource } \\
\text { Compared to } \\
\text { US Cumulative Uses } \\
(1975 \text { to 2040)(b) }\end{array}$ & $\begin{array}{c}\text { Current } \\
\text { Source of } \\
\text { Material Supply }(c)\end{array}$ \\
\hline $\begin{array}{l}\text { Beryllium } \\
\text { Chromium } \\
\text { Copper } \\
\text { Hel ium } \\
\text { Iron } \\
\text { Lead } \\
\text { Lithium } \\
\text { Mercury } \\
\text { Molybdenum } \\
\text { Nickel }\end{array}$ & $\begin{array}{l}2 \\
2 \\
1 \\
3 \\
1 \\
2 \\
2 \\
2 \\
2,3 \\
2\end{array}$ & $\begin{array}{l}2,4,6,7 \\
2,3,6,7 \\
2,4,5,7 \\
2 \\
2,4,5,7 \\
2,4,6,7 \\
2,4,6,7 \\
2,4,6,7 \\
2,4,5,7 \\
2,4,6,7\end{array}$ & $\begin{array}{l}2 \\
4 \\
2 \\
5 \\
2 \\
1 \\
1 \\
3 \\
1,5 \\
3\end{array}$ \\
\hline
\end{tabular}

(a) Production Capacity Compared to Expected Use Rates

1. Planned production capacity greater than expected U.S. use rates with and without fusion power plant uses.

2. Additional production capacity development needed as a result of fusion power plant construction.

3. Production is a by-product of production of another material.

(b) Reserves and Resources Compared to Cumulative Use $(1975-2040)$

1. U.S. reserves greater than expected U.S. cumulative use

2. U.S. reserves less than expected U.S. cumulative use

3. World reserves greater than expected U.S. cumulative use. (b) Continued

4. World reserves less than expected U.S. cumulative

5. U.S. resource greater than expected U.S. cumulative

6. U.S. resource less than expected U.S. cumulative use

7. Worid resource greater than expected U.S. cimulative use

8. Horld resource less than expected U.S. cumulative use

(c) Source of Material supply

1. Less than 10\% dependent on foreign supply

2. Less than $50 \%$ dependent on foreign supply

3. Less than $75 \%$ dependent on foreign supply

4. Totally dependent on foreign supply

5. By-product of production of another material 
The quantities of select metals used in the United States in 1974 and the percentage domestically produced is shown in Table 25 while the following paragraphs discuss expected future availability of individual materials.

TABLE 25. Quantities of Select Metals Used in the U.S. in 1974 and Percentage Domestically Produced(a)

\begin{tabular}{|c|c|c|}
\hline Metal & $\begin{array}{l}1000 \\
\text { Metric Tons } \\
\end{array}$ & $\begin{array}{c}\% \text { Domestically } \\
\text { Produced }\end{array}$ \\
\hline Raw Steel & 132,000 & 60 \\
\hline $\begin{array}{l}\text { Aluminum } \\
\text { Copper } \\
\text { Manganese } \\
\text { Lead } \\
\text { Zinc }\end{array}$ & $\begin{array}{l}5,700 \\
2,000 \\
1,400 \\
1,500 \\
1,200\end{array}$ & $\begin{array}{r}10 \\
90 \\
0 \\
90 \\
50\end{array}$ \\
\hline $\begin{array}{l}\text { Nickel } \\
\text { Chromium } \\
\text { Magnesium }\end{array}$ & $\begin{array}{l}190 \\
510 \\
120\end{array}$ & $\begin{array}{r}10 \\
0 \\
50\end{array}$ \\
\hline $\begin{array}{l}\text { Molybdenum } \\
\text { Tin } \\
\text { Titanium } \\
\text { Tungsten }\end{array}$ & $\begin{array}{l}69 \\
58 \\
25 \\
15\end{array}$ & $\begin{array}{r}100 \\
0 \\
0 \\
50\end{array}$ \\
\hline Cobalt & 8.6 & 0 \\
\hline Bery 11 ium & 0.19 & 100 \\
\hline
\end{tabular}

(a) Source: Commodity Data Summaries, U.S. Bureau of Mines, 1976.(33)

- CHROMIUM. As shown in Table 21, world resources of chromium are greater than expected U.S. cumulative use, but U.S. resources are less than expected U.S. cumulative use, with or without fusion power plants. There are no U.S. resources of chromium at current prices and technology. Also, the one currently profitable source of this essential (18 to 33\%) component of stainless steel, the mineral chromite, is not being mined in the United States. Greater than 1 million MT of chromium resources have been identified in the U.S., but they are not currently considered to be reserves and are not expected to become reserves in the foreseeable future. In 1973, $70 \%$ of U.S. chrome was imported while $20 \%$ came from strategic stockpile sales and 10\% from secondary recovery. The import sources in 1973 were S. Africa, $31 \%$; USSR, 21\%; Rhodesia, 13\%; Turkey, $11 \%$; Philippines, $11 \%$; and remaining $13 \%$ from a number of small producers. Because of the small number of producers, the potential exists for a cartel which could cause significant price increases for short periods. However, significant price increases due only to increasing world scarcity of chrome are not expected in the foreseeable future.

- NICKEL. Currently, world resources and reserves of nickel are less than expected U.S. cumulative use with fusion power plants and they are only somewhat greater than U.S. cumulative use without fusion power plants. As is true with chromium, this metal is consumed in large quantities in steel making. U.S. nickel production provides only 5 to $10 \%$ of the nickel consumed in the U.S. with secondary sources providing about 30\%. The remaining 60 to $65 \%$ are imported primarily from Canada with small amounts from the Dominican Republic and Norway. 
Domestic nickel reserves are very small ( 180,000 MT nickel) while resources are estimated to be greater than 13 million MT. A large increase in nickel prices could transform much of these resources into reserves. Also, known world nickel resources are increasing rapidly with new laterite developments. Sea floor nodules probably contain several hundred million metric tons of nickel. Resolution of political and technological difficulties could result in large quantities of nickel, copper, cobalt and manganese reserves from these resources.

- IRON ORE. U.S. reserves are less than expected U.S. cumulative use to 2040 with or without fusion power plants, but U.S. and world resources are greater than expected U.S. cumulative use. Significant long-term iron ore price increases are not expected even if nationalization of U.S. -owned iron ore production facilities in foreign countries occurs. Only about $30 \%$ of the iron ore used in the U.S. each year is imported. Delays in adding to production capacity could cause temporary shortages and high prices of iron as the use of this material for fusion power plants is added to other uses.

- ALUMINUM. U.S. reserves of the currently used aluminum ore, bauxite, are much less than current annual U.S. consumption. Domestic resources are greater than 1 trillion MT of aluminum which is considerably larger than expected U.S. cumulative consumption. Conversion to use of domestic resources such as clays, shales and other lower grade sources of aluminum would reduce reliance on imports.

- MERCURY. Currently, there is no mercury mined in the U.S. Although there are large U.S. resources (greater than 0.1 million MT), they are still less than expected domestic uses of mercury with or without fusion power plants. World reserves are less than expected U.S. cumulative use to 2040 while world resources are greater than expected U.S. consumption.

- LEAD. U.S. and world reserves are less than expected U.S. cumulative use to 2040. World reported resources are less than expected U.S. cumulative use to 2040. Significant lead time should be expected for expansion of production capacity.

- COPPER. U.S. and world reserves are less than expected U.S. cumulative use to 2040 with or without fusion power plants. Also U.S. resources are less than expected U.S. cumulative use, and world resources are greater than expected U.S. cumulative use to 2040. Significant lead time for expansion of production capacity should be expected.

- MOLYBDENUM. U.S. and world reserves are less than expected U.S. cumulative use to 2040 with or without fusion power plants. U.S. and world resources are very large compared to U.S. cumulative use of molybdenum.

- HELIUM. U.S. reserves and resources of helium are less than their expected U.S. cumulative use to 2040. No reliable data are available on world reserves or resources of helium. Natural gas is the primary source of helium.

- BERYLLIUM. Information on beryllium reserves and resources is very incomplete and unreliable. Data on world reserves of beryllium are essentially nonexistent while data on world resources are very conservative. The world cumulative use of beryllium to 2040 is expected to be greater than the world resources currently reported in the literature. 
- NIOBIUM. U.S. reserves and resources are negligible. Most of the niobium used in the U.S. is currently imported from Brazil. World resources (greater than $18 \mathrm{million}$ MT) are expected to be larger than U.S. cumulative use to 2040 with or without fusion power plants.

- MANGANESE. The U.S. has no reserves of manganese, and hence imports all of this metal which is used in the steel industry. However, world reserves are very large compared to U.S. expected cumulative use to 2040 .

- LITHILM. Fusion power plants are expected to use relatively large amounts of lithium compared to current U.S. production, but small when compared to the total U.S. resources. Further, significant price increases would not cause the substitution of other materials for 1 ithium in fusion power plants because of the high energy content of Liasa fusion fuel. For more detail on lithium supply see BNWL-2012. (34)

- Additional information on select materials can be found in Appendix B.

Long lead times are involved in the exploration and development of reserves and the construction of production capacity. For example, to develop reserves takes from 8 to 20 years (in genera1) from the time of initial exploration, mine development takes up to 8 years, and construction of final production and fabrication facilities could take up to 5 years. Thus, the total lead time could be as long as 16 to 30 years.

Industrial capacity must be increased faster than currently planned to produce fuston power plant materials and elements including stainless steels, nickel-base alloys, boron, beryllium, chromium, helium, lithium, molybdenum, niobium, lead, tantalum, vanadium, and yttrium.

Other factors that could affect material availability but which were not extensively reviewed in this report are: geologic environment, geographic distribution and political influences. The uneven distribution of the geologic environments for various mineral deposits is the basic element in the structure of the mineral industry. The inequality of the geographic distribution of mineral deposits has had an affect on the political and economic availability of many materials (Table 26). These inequalities of distribution of minerals are complicated by the effects of various political climates. Wars, nationalism, cartels, demands for more control, high taxation, expropriation etc. lead to the need for industry to have diversified sources of raw materials.

\section{POTENTIAL ENVIRONMENTAL IMPACTS OF MATERIALS PROCUREMENT FOR FUSION POWER PLANTS}

Procurement of materials will result in environmental impacts from the mining, milling, and processing operations. Mining operations change the land and water use by releasing chemicals and other materials. Milling and processing operations have impacts on land occupancy and from releases of chemicals to water and air. These environmental impacts are discussed in the following subsections. 
TABLE 26. Percentage Distribution of 1967 World Mineral Production for Select Materials

\begin{tabular}{|c|c|c|c|c|c|c|c|}
\hline Material & $\begin{array}{c}\text { North } \\
\text { America }\end{array}$ & $\begin{array}{c}\text { South } \\
\text { America }\end{array}$ & Europe & Africa & Asia & Oceania & Communist \\
\hline Aluminum & 27.8 & 20.1 & 30.8 & 5.2 & 6.6 & 9.5 & 16.2 \\
\hline Chromium & 0.6 & 0.1 & 40.1 & 30.9 & 28.3 & -- & 38.8 \\
\hline Copper & 29.9 & 17.1 & 20.2 & 23.8 & 7.2 & 1.8 & 19.3 \\
\hline Iron & 20.7 & 9.5 & 48.2 & 6.0 & 12.5 & 3.0 & 34.4 \\
\hline Lead & 26.8 & 8.0 & 36.3 & 6.5 & 9.4 & 13.1 & 26.3 \\
\hline Magnes ium & 52.6 & -- & 43.4 & -- & 4.0 & -- & 22.3 \\
\hline Mercury & 19.7 & 1.3 & 66.2 & 0.1 & 12.7 & -- & 27.4 \\
\hline Molybdenum & 76.7 & 8.9 & 11.2 & - & 3.2 & -- & 13.1 \\
\hline Nickel & 60.2 & 0.2 & 22.7 & 1.5 & 1.4 & 14.0 & 28.1 \\
\hline
\end{tabular}

\section{Land Alteration by Mining}

Land is altered in several ways by mining. Strip mining completely alters the surface since it removes and replaces overburden. All vegetation is destroyed and mobile life forms are either displaced or destroyed. However, proper restoration practices could return land to its former condition after completion of the mining at some expense.

Underground mining requires that the ground surface be occupied by buildings, facilities, waste piles, and waste ponds. All life forms on these surface lands are displaced and destroyed, and much of the land is rendered less productive for other purposes because of the installation of permanent structures or because of the nature of the waste materials placed on the land. Further, the land may be altered by the subsidence that may occur as abandoned mining shafts cave in. This subsidence temporarily alters the surface conditions, possibly causing severe damage to structures and pollution of water bodies until the land surface is stabilized.

\section{Chemical Release}

Chemicals and other materials may be released to water bodies as a result of erosion of waste piles and loosened earth or as a result of dissolution of minerals exposed by mining operations. Often the land can no longer support profitable agricultural activities or lumber production for a long period after mining ceases. An adverse aesthetic impact could result from the presence of waste piles, structures, or barren ground in contrast to former forest, desert, or agricultural lands.

Proper design of waste piles, strip mines, and other surface locations that are subject to washing by rainwater will generally prevent washing of these materials into nearby bodies of water. Similarly, proper control of mine waters will minimize the amounts of dissolved materials entering nearby water bodies. Of course, these precautions increase mining costs.

During milling operations land is occupied by the process buildings, waste piles, and waste ponds. This land may become less productive because the chemicals in the water inhibit plant 
growth. Chemical releases can be prevented from having adverse impacts through use of modern waste control technology, although this is accompanied by increased costs and land use for waste storage.

Processing operations to convert the concentrated ore into pure metals and fabricated equipment also use land and release chemicals. These impacts are quite similar to those for milling operations except that less land is used for waste disposal because there is no need to dispose of large quantities of gangue materials. Milling and processing operations may have significant adverse impacts due to heat releases, noise, and odors. These impacts can be kept insignificant through remote location of operations and use of current control technology at moderate cost.

\section{Summary of Estimated Environmental Impacts}

Information is not readily available on the average impacts due to procurement of most materials. Surveys have not been made to determine the average quantities of land alteration and chemical releases per ton of material produced. As a result, the actual impacts cannot be specified accurately. The amount of land required for the mining and disposing of the waste materials from mining was used as a general measure of the impact of material procurement. Generally, this land usage represents a majority of the known impacts, particularly if the chemicals and heat are released according to appropriate standards. The alteration of land for mining usually is much larger than for milling and processing.

As estimate of the amount of land altered for construction of a 1000-Mwe fusion power plant is presented in Table 27. This estimate is based on the assumption that the average mining conditions are:

- strip mining to a depth of 25 meters,

- an ore and waste (overburden) average density of $3.0 \mathrm{~kg} / 1 \mathrm{iter}$,

- as much land needed for handling and storing the overburden as is needed for the strip mine,

- ore concentrations equal to those of currently profitably mineable ores,

- restoration of $50 \%$ of the altered land to its original condition, and

- current mine stripping ratios (waste volume/ore volume).

The quantities of the materials used in the fusion power plant construction are based on the estimates for the UWMAK-I tokamak.

This analysis indicates that about $0.16 \mathrm{~km}^{2}$ (40 acres) of land probably would be altered as a result of construction of 1000-MWe fusion reactor power plant. Most of this land alteration is due to mining of copper, molybdenum and nickel. The actual land alteration appears to be primarily dependent on the quantities of these materials used and the mining conditions. 
TABLE 27. Estimated Land Alterations for Mining of Materials for Fusion Power Plants

\begin{tabular}{|c|c|c|c|c|c|c|c|c|}
\hline Material & $\begin{array}{l}\text { Est imated Conc. } \\
\text { of Metal in } \\
\text { Resource, } \$ \\
\end{array}$ & $\begin{array}{l}\text { Estima ted } \\
\text { Metric Tons of } \\
\text { Ore/MT of otal }\end{array}$ & $\begin{array}{l}\text { Assumed } \\
\text { Stripping } \\
\text { Ratio } \\
\end{array}$ & $\begin{array}{l}\text { Metric } \\
\text { Tons } \\
\text { Waste } \\
+ \text { Ore/MT } \\
\text { Metal } \\
\end{array}$ & $\begin{array}{l}\text { Metric } \\
\text { Tons } \\
\text { Metal/Mine } \\
\end{array}$ & $\begin{array}{l}\text { Metric } \\
\text { Tons } \\
+ \text { Waste } \\
\text { Ore/Mte } \\
\end{array}$ & $\begin{array}{c}\text { Land Alteration (a) } \\
M^{2} / \text { mee } \\
\end{array}$ & $\begin{array}{c}\text { Land Alteration } \\
\mathbf{k m}^{2} / \\
1,000 \text { Mue } \\
\end{array}$ \\
\hline Aluminum & 19.0 & 5.3 & 1.0 & 11 & 0.54 & 6 & & \\
\hline Boron & 6.0 & 17 & 1.0 & 34 & 1.07 & 36 & & \\
\hline Chromium & 6.8 & 15 & 1.0 & 30 & 7.92 & 238 & & \\
\hline Copper & 0.3 & 333 & 2.0 & 1,000 & 7.27 & 7,270 & & \\
\hline Hel ium & -- & -- & -- & -- & -- & -- & & \\
\hline Iron & 30.3 & 3.3 & 2.0 & 10 & 77.8 & 778 & & \\
\hline Lead & 3.0 & 33 & 0.5 & 50 & 13.9 & 695 & & \\
\hline Lithium & 0.5 & 200 & 1.0 & 400 & 1.15 & 460 & & \\
\hline Manganese & 30.0 & 3.3 & 1.0 & 66 & 0.82 & 54 & & \\
\hline Mercury & 0.1 & 1,000 & 1.0 & 2,000 & 0.002 & 4 & & \\
\hline Molybdenum & 0.12 & 830 & 2.0 & 2,500 & 0.41 & 1,025 & & \\
\hline Nickel & 1.0 & 100 & 1.0 & 200 & 5.9 & 1,180 & & \\
\hline Niobium & 0.2 & 480 & 2.0 & 1,440 & 0.09 & 130 & & \\
\hline Sodium & 22.0 & 4.6 & 0.1 & 5.1 & 12.1 & 62 & & \\
\hline Titanium & 1.2 & 83 & 1.1 & 174 & 0.05 & 9 & & \\
\hline Yttrium & 1.0 & 100 & 1.1 & 210 & 0.003 & 1 & & \\
\hline \multirow[t]{2}{*}{ Zirconium } & 0.2 & 500 & 0.1 & 550 & 0.07 & 39 & $\ldots$ & \\
\hline & & & & & & 11,987 & 160 & 0.1610 \\
\hline
\end{tabular}

(a) Based on density of $3.0 \mathrm{~kg} / 1$, mining depth of 25 meters plus an equal amount of land needed to handle overburden and $50 \%$ reclamation. 
APPENDIX A 
APPENDIX A

\section{DESCRIPTION OF THE EXPLOR-MULTITRADE PROGRAM}

Input/output analysis answers the basic question: At what level of output will each industry in the economy operate to produce the total product of all industries? The cormodity produced in some industries (e.g., the primary metals) becomes input to other industries, expressed in input/output analysis as a fixed proportion per unit of output of each industry. Therefore, the output level of primary metals is given by the input of these metals to other industries which is in turn dependent on the output level of all the industries in the economy. Since other industries provide input to the primary metals industry, their output is dependent on the input mix and the output level of the primary metals industry. Because of this interdependence, any projected output levels for all industries are consistent with all input levels in the economy. Input/output analyses will only predict a level of metals output that is consistent in the input/output sense with the rest of the economy.

The core of the EXPLOR-MULTITRADE model is a commodity-by-conmodity input/output accounting system. The system begins with historic inter-industry flow matrices where an element in the $i^{\text {th }}$ row and the $j^{\text {th }}$ column represent the dollar value of an input of the $i^{\text {th }}$ commodity to the production of the $j^{\text {th }}$ commodity. These inter-industry flow matrices are converted to technical coefficient matrices by dividing each column by the constant dollar value of the output of the commodity corresponding to that column. Time trend analyses of the technological makeup of the economy, modified by expert opinion, are then used to estimate the shifts which will occur in these matrices in the future.

With the projected matrix of technical coefficients and exogenous forecasts of the components of final demand, prices, profits, and additional components of value added, EXPLORMULTITRADE iterates to a consistent solution for the entire economy of a country. The computer program attempts to get as close as possible to estimated prices and profits for all commodities subject to the many economic constraints embodied in the code. In effect, the program gives credance to the best estimates of the forecaster but forces the results to be compatible within themseives. A benefit to using a computer code such as this is that wild projections of material use without the necessary final demand will not be allowed. Final demand in input/output analysis refers to all sales of a commodity which are not used as input to the production process of any industry. This includes private expenditure, exports net of imports, capital expenditure, government expenditure, investment in dwellings, and changes in inventory.

The technical coefficients were aggregated from 129 sector detail technical coefficients supplied by the Bureau of Labor Statistics to 80 sector detail and were projected for future years. Further aggregation was done to make room for the critical materials that are examined in this assessment. Coefficients were developed for the critical materials which were not discernible from the BLS data due to the level of aggregation. These coefficients are shown in Table A.1 along with the SIC classification of the sectors which use the materials as inputs in 
production. The coefficients in Table A.1 were developed from time series data in the Bureau of Mines documents; Minerals in the U.S. Economy ${ }^{(35)}$ and Commodity Data Summaries 1974: Appendix I to Mining and Mineral Policy. ${ }^{(36)}$ Coefficients for iron ore, copper ore, lithium, and lead were already in the earlier data base.

TABLE A.1. Technical Coefficients Representing Sales of Critical Materials to Other EXPLOR Sectors

\begin{tabular}{|c|c|c|c|c|c|c|c|}
\hline $\begin{array}{l}\text { EXPLOR } \\
\text { SECTOR } \\
\end{array}$ & $\begin{array}{c}\text { SIC } \\
\text { Classification } \\
\end{array}$ & Beryllium & Chromium & Helium & Mercury & Molybdenum & Nickel \\
\hline 9 & 29 & & & & & & 0.00120 \\
\hline 10 & 491 and part 493 & & & 0.00002 & & & \\
\hline 11 & 492 and part 493 & & & & & 0.00113 & \\
\hline 27 & $324-329$ & & 0.00398 & & & & \\
\hline 29 & $\begin{array}{l}281,286,287,289 \\
\text { (except } 28195)\end{array}$ & & 0.00115 & & 0.00025 & 0.00035 & 0.00303 \\
\hline 32 & 285 & & & & 0.00110 & & \\
\hline 39 & $\begin{array}{l}(3331,2,4,9), \\
334,28195, \\
(3351,2,6,7), \\
336,3392\end{array}$ & & & 0.00010 & & & \\
\hline 40 & 341,3491 & & 0.00258 & 0.00012 & & & 0.00374 \\
\hline 43 & $\begin{array}{l}342,347,348,349 \\
\text { except } 3491\end{array}$ & & 0.00049 & & & & \\
\hline 44 & 351 & & 0.01055 & & & & \\
\hline 48 & $(354-356)$ & & & & & 0.00081 & 0.00126 \\
\hline 52 & 361,362 & & & & & & 0.00625 \\
\hline 53 & 363 & & 0.00215 & & & & 0.00600 \\
\hline 54 & 364 & 0.00435 & & & & & \\
\hline 56 & 367 & 0.00082 & & & & 0.00034 & \\
\hline 57 & 369 & & & & 0.00202 & & \\
\hline 58 & $381,382,384,387$ & & & 0.00025 & 0.00070 & & \\
\hline 59 & $383,385,386$ & & & 0.00014 & & & \\
\hline 61 & 371 & & 0.00083 & & & & 0.00112 \\
\hline 62 & 372 & 0.00021 & & 0.00009 & & 0.00134 & 0.00186 \\
\hline 63 & 19 & & & 0.00077 & & & \\
\hline 64 & $374,375,379,373$ & & & & & & 0.00249 \\
\hline 69 & $\begin{array}{l}(60-67), 70,72,73 \\
75,76,(78-82)\end{array}$ & & & 0.00001 & & & \\
\hline 78 & part of 491 and 493 & & & 0.00002 & & & \\
\hline 79 & part of 491 and 493 & & & 0.00002 & & & \\
\hline 80 & part of 491 and 493 & & & 0.00002 & & & \\
\hline
\end{tabular}


APPENDIX B

1

$\mathbf{x}$ 


\section{APPENDIX B}

\section{SUPPLY OF SELECTED MATERIALS}

The information in this appendix discusses the sources for selected materials used domestically. (26)

\section{ALUMINUM}

Domestic production of bauxite, the current raw material used for production of aluminum, is the source of only 10 to $15 \%$ of U.S. bauxite consumption. Even this small fraction has been waning (28) due to the substantial increase in imports of alumina, as well as bauxite, in the past 5 years. Major U.S. sources of bauxite are Jamaica, Surinam, Dominican Republic, and Guyana, while Australia, Jamaica, and Suriname provide the U.S. with alumina. Although these sources are considered stable, cartelization could temporarily raise prices dramatically. Given high enough aluminum prices and low cost energy, abundant low-grade U.S. resources (such as the Georgia kaolins) could become reserves.

Domestic production of primary and secondary aluminum typically provides more than $90 \%$ of the aluminum consumed annually in the U.S. The majority of aluminum that is imported comes from Canada. Domestic primary aluminum capacity is estimated to be $32 \%$ of total world capacity, and from 1972 to 1974 the U.S. accounted for 34 to $35 \%$ of estimated world production.

COPPER

The copper industry has historically been marked by large recurrent fluctuations in the price of its output. Because of this, the domestic copper industry (mines, smelters, refineries) has less capacity than if the price of copper had stabilized at its highest levels and more capacity than if it had stabilized at its lowest levels. The U.S. is a net importer of copper in ore, blister, and refined forms. Domestic mine production is slightly less than smelter capacity, which in turn is slightly less than refinery capacity, which in turn is slightly less than domestic consumption. Nevertheless, the domestic refining industry is typically the source of $90 \%$ or more of the domestic copper used while domestic mines are typically the source of about $75 \%$ of domestic consumption. (28) About $20 \%$ of the copper used domestically comes from the domestic secondary copper industry which salvages used copper from Canada, Peru, and Chile. From 1972 to 1974 , domestic mines accounted for 20 to $22 \%$ of the world mine production of copper. This pattern is not expected to change in the foreseeable future.

\section{FLUORINE}

The use of fluorine in the manufacture of industrial chemicals comprises about $1 / 3$ of the total market for fluorspar, which is the primary raw material. (37) Although flibe is not now a significant product of this industry, its manufacture would very conveniently fit chemical plant 
operations. (38) Beryllium fluoride is an intermediate product in the manufacture of beryllium metal, and lithium fluoride is widely used as a flux. Thus, fluorine use is directly related to the beryllium and lithium industries.

From 1970 to 1974, domestic production of fluorspar decreased from about 20 to $15 \%$ of domestic use. (28) Thus, the domestic fluorine industry is getting a growing fraction of its primary raw material from foreign sources, principally from Mexico, but also from Spain and Italy. These sources of supply presently appear stable, but cartel action is a possibility. Domestic fluorine production as a by-product of phosphate processing is fostered by environmental regulations. Increased costs resulting from depletion of the highest quality fluorspar deposits and from these environmental regulations could result in fluorine production from phosphate rock treatment providing all of the fluorine used in the U.S. by the year 2000 .

IRON

Currently, imports (chiefly from Canada and Venezuela) account for roughly $1 / 3$ of the iron ore consumed by the domestic iron and steel industry. (28) The U.S. is also a net importer of iron and steel products, with imports exceeding exports by about 3 to 5 times from 1970 to 1974 . However, shipments from domestic mills provided about $92 \%$ of the domestic iron and steel used from 1973 to 1974 ; this is an increase from about $85 \%$ from 1971 to 1972 .

\section{MERCURY}

The fusion power plant use of mercury in vacuum pumps is small relative to the available projections of domestic use of mercury for other purposes. Worldwide mercury consumption is presently projected to grow at a compound annual rate of $2.2 \%$ through the end of this century. (39) Growth in domestic use of mercury is expected to be slower than this. (28) Environmental pressures have recently reduced the growth in domestic mercury consumption, and annual consumption through the early 1970 s remained between 50 and 60 thousand flasks, down from the 70 to 100 thousand flasks/year level of the mid and late 1960 s.

Domestic primary production of mercury in the past 5 years has decreased markedly in the face of falling prices for mercury since the late 1960s. In 1970, domestic primary and secondary production accounted for 44 and 13\% of domestic consumption, respectively; in 1974 domestic primary production provided $3 \%$ of the mercury used domestically and secondary production provided $15 \%$. (28) Even if, for example, one company achieves their stated goal of bringing on line in 1976 a primary plant capable of producing about 1/3 of current U.S. annual use, the U.S. will continue to rely heavily on foreign sources, barring a large upturn in price or technological improvements. (Environmental regulations have increased the cost of producing mercury in the U.S. with current technology.) Canada is the major source of mercury for the U.S., while Algeria, Mexico, and Spain are also important sources. 


\section{MANGANESE}

The U.S. steel industry imports all of the manganese ore it uses from Brazil, Gabon, South Africa, and Zaire. Imports of ferro-manganese from South Africa, France, and India have been steadily increasing in proportion to domestic production of ferro-manganese from imported ore. Nearly all of the manganese used in fusion power plants and otherwise is expected to be employed in making steel. Development of deep-sea nodule resources could greatly increase manganese reserves.

TIN

Domestic mine production of tin is miniscule, and domestic smelting of principally imported ore provides less than $10 \%$ of the domestically consumed tin; the domestic secondary industry provides roughly another 1/4 of domestic use. Thus, the U.S. imports most of the tin it uses. Malaysia and Thailand are the major sources of primary tin for the U.S. (29) The development of substitutes for tin in several applications has resulted in about constant domestic use of tin for several years. By virtue of control exercised by the International Tin Council, tin prices are not expected to increase dramatically in the near future. The amount of tin expected to be used in fusion power plants is small compared to other uses.

\section{TITANIUM AND ZIRCONIUM}

Almost all of the ore from which titanium is made (rutile) is imported from Australia. However, illeminite (a potential titanium ore) is produced domestically in amounts sufficient to provide for 70 to $80 \%$ of domestic uses given higher titanium prices or new technology. The U.S. is also a net importer of titanium metal (sponge), primarily from Japan, the Soviet Union, and the United Kingdom. Sponge imports typically supply about $1 / 4$ of domestic uses. Domestic industry provides virtually all of the mill products used domestically.

Roughly half of the zircon used in the U.S. is provided by Australia with the balance produced domestically. However, the U.S. is a net exporter of zirconium metal.

Domestic industrial production of both metals is expected to grow at a rapid rate. Foreign ore imports will probably continue for the foreseeable future. The use of these metals in fusion power plants is small compared to other uses of these materials and compared to the use of other materials in fusion power plants. 


\section{GLOSSARY}


Resource - includes undiscovered mineral deposits and reserves as well as identified mineral deposits that cannot be profitably recovered at current prices using current technology (see "Reserves and Resources" for additional details).

Reserves - quantities of ore minerals located in identified deposits that can be developed profitably at current prices using current technology (see "Reserves and Resources" for additional details).

Availability - a material is said to be "available" when its price is not so high relative to other goods and services and to peoples' incomes that "many" people will choose not to buy "very much" of it. This availability is determined by an interaction between the supply of and the demand for each material (see "The Meaning of Availability" for further details).

Geochemically abundant elements - those elements that are present in the earth's crust in quantities equal to or greater than $0.1 \%$ of the whole mass. Twelve elements account for $99.23 \%$ of the mass of the crust.

Geochemically scarce elements - those elements that are present in the earth's crust in quantities less than $0.1 \%$ of the whole mass. Seventy-six elements account for a mere $0.77 \%$ of the mass.

Critical materials - those materials where construction of 25 fusion power plants/year would require more than $1 \%$ of the present consumption of that material or where domestic reserves were considered to be very small compared to current use rates. 


\section{REFERENCES}

1. B. Badger et al. (22 authors), UWMAK-I, A Wisconsin Toroidal Fusion Reactor Design. II. UWFDM-68, University of Wiscons in, May 1975.

2. B. Badger et a1. (30 authors), UWMAK-II, A Conceptual Tokamak Power Reactor Design. UWFDM-112, University of Wisconsin, October 1975.

3. R. G. Mills, Ed., A Fusion Power Plant. MATT-1050, Princeton Plasma Physics Laboratory, 1974.

4. A. P. Fraas, Conceptual Design of the Blanket and Shield Region and Related Systems for a Full Scale Toroidal Fusion Reactor. ORNL-TM-3096, May 1973.

5. J. E. Draley, R. A. Krakowski, T. A. Coultas, and V. A. Maroni, An Engineering Design Study of a Reference Theta-Pinch Reactor (RTPR): Environmental Impact Study. LA-5336, ANL-8079 (joint report), II, March 1975.

6. R. W. Werner, G. A. Carlson, J. Hovingh, J. D. Lee and M. A. Peterson, Progress Report No. 2 on the Design Considerations for a Low Power Experimental Mirror Fusion Reactor. UCRL-74054-2, September 1973.

7. J. R. Powell, Ed., Preliminary Reference Design of a Fusion Reactor Exhibiting Very Low Residual Radioactivity. BNL-19565, Brookhaven National Laboratory, December 1974.

8. Roger W. A. Legassie, Assistant Administrator for Planning and Analysis, Energy Research and Development Administration, "Total Energy, Electric Energy, and Nuclear Power Projections, United States, February 1974," in Oversight Hearings on Nuclear Energy - Overview of the Major Issues." Hearings before the Subcomittee on Energy and the Environment of the Committee on Interior and Insular Affairs, House of Representatives, 94th Congress, April 28 to May 2, 1975, Serial No. 94-16, Part I, Washington, DC, USGPO.

9. U.S. Atomic Energy Commission, Proposed Final Environmental Statement, Liquid Metal Fast Breeder Reactor Program. WASH-1535, December 1974.

10. T. B. Cochran, The Liquid Metal Fast Breeder Reactor: An Economic and Environmental Critique. Published by Resources for the Future, Inc., Distributed by Johns Hopkins University Press, Baltimore and London, 1974.

11. Energy Policy Project of the Ford Foundation, A Time to Choose: America's Energy Future. Ballinger Publishing Company, Cambridge, MA, 1974 .

12. L. E. Erickson, Regional Analysis of the U.S. Electric Power Industry, Volume 3, Regional Demand Analysis and Consumption Forecasts. BNWL-B415 V3, Battelle-Northwest, Richland, WA, June 1975.

13. U.S. Bureau of the Census, Current Population Reports, Series P-25, No. 601, "Projections of the Population of the United States: 1975 to 2050." U.S. Government Printing Office, Washington, DC, October 1975.

14. E. F. Denison, Accounting for United States Economic Growth, 1929-1969. The Brookings Institution, Washington, DC, p. 16, 1974.

15. Federal Power Commission, 1970 National Power Survey. U.S. Government Printing Office, Washington, DC, 1970.

16. Task Force on Forecast Review, Forecasts of Electricity Energy and Demand to the Year 2000. A Report to the Technical Advisory Committee on Power Supply, National Power Survey, August 24, 1973 (unpublished).

17. L. E. Erickson, "A Review of Forecasts for U.S. Energy Consumption in 1980 and 2000," in Energy and Human Welfare, A Critical Analysis. Volume II, Chapter I, edited by Barry Commoner, Howard Boksenbaum, and Michael Corr, Macmillan Information, Division of Macmillan Publishing Company, Riverside, NJ, 1975.

18. W. N. Aspinall, Chairman, Committee on Interior and Insular Affairs, U.S. House of Representatives, Energy "Demand" Studies, an Analysis and Appraisal. U.S. Government Printing office, Washington, DC, September 1972. 
19. Senator H. M. Jackson, Chairman, Committee on Interior and Insular Affairs, United States Senate, Survey of Energy Consumption Projections. Pursuant to Senate Resolution 45, A National Fuels and Energy Policy Study, Serial No. 92-19, U.S. Government Printing 0ffice, Washington, DC, 1972.

20. T. J. Tyrrel 1, Projections of Electricity Demand. ORNL-NSF-EP-50, Oak Ridge National Laboratory, Oak Ridge, TN, November 1973.

21. T. D. Mount, L. D. Chapman, and T. J. Tyrrell, Electricity Demand in the United States: An Econometric Analysis. ORNL-NSF-EP-49, Oak Ridge National Laboratory, Dak Ridge, TN, June 1973.

22. N. D. Uri, Towards an Efficient Allocation of Electrical Energy. Lexington Books, D.C. Heath and Company, Lexington, MA, 1975.

23. R. L. Engel, Regional Analys is of the U.S. Electric Power Industry, Vol. 2, Linear Programming Simulation. BNWL -B-415 V2, Battelle, Pacific Northwest Laboratories, Richland, WA 99352, June 1975.

24. Central Station Nuclear Plants, Office of Industry State and Local Relations, ERDA Quarterly Report.

25. Monthly Energy Review, Federal Energy Administration National Energy Information Center.

26. Assessment of Material Needs for Fusion Reactors. Compiled by G. A. Allison, BNWL-1933, Battelle, Pacific Northwest Laboratories, Richland, WA 99352, Vol. 1, June 1976.

27. U.S. Geological Survey, United States Mineral Resources, D. A. Brobst and W. P. Pratt (Editors), Professional Paper 820, 1973.

28. U.S. Bureau of Mine Commodity Data Sumaries, 1975.

29. U.S. Bureau of Mines Mineral Yearbook, 1973.

30. E. N. Cameron, University of Wisconsin, Preliminary Report on Availability of Metals for the UW Tokamak, June 1974.

31. Council on International Economic Policy, Executive Office of the President, Special ReportCritical Imported Materials. Government Printing Office, Washington, DC, December 1974.

32. T. Lee and C. L. Yao, "Abundance of Chemical Elements in the Earth's Crust and Its Major Tectonic Units," International Geology Review. 12(7):776-778, 1970.

33. Commodity Data Summaries, U.S. Bureau of Mines, 1976.

34. B. F. Gore and P. L. Hendrickson, Fuel Procurement for First Generation Fusion Power Plants. BNWL-2010, Apri1 1976.

35. U.S. Bureau of Mines, Minerals in the U.S. Economy: Ten-Year Supply-Denand Profiles for Mineral and Fuel Commodities.

36. U.S. Bureau of Mines, Commodity Data Summaries 1974: Appendix 1 to Mining and Minerals Policy.

37. Personal Communications from S. Roboff, Kawecki Berylco Industries, and N. Bass and S. Zenczak, Brush-Wel lman, Inc. 
A. A. Churm ERDA Chicago Patent Group $9800 \mathrm{~S}$. Cass Avenue Argonne, IL 60439

J. W. Beal

ERDA Div. of Magnetic Fusion Energy Washington, DC 20545

S. 0. Dean

ERDA Div. of Magnetic

Fusion Energy

Washington, DC 20545

E. E. Kintner

ERDA Div. of Magnetic Fusion Energy Washington, DC 20545

J. M. Williams

ERDA Div. of Magnetic Fusion Energy

Washington, DC 20545

J. N. Grace

ERDA Div. of Magnetic

Fusion Energy

Washington, DC 20545

J. Baublitz

ERDA Div. of Magnetic

Fusion Energy

Washington, DC 20545

3 F. E. Coffman

ERDA Div. of Magnetic

Fusion Energy

Washington, DC 20545

J. F. Decker

ERDA Div. of Magnetic

Fusion Energy

Washington, DC 20545

3 K. M. Zwilsky

ERDA Div. of Magnetic Fusion Energy

Washington, DC 20545

Dr. Philip M. Stone

ERDA Applied Plasma Physics

Program

Washington, DC 20545

G. W. Kuswa

ERDA Div. of Laser Fusion

Washington, DC 20545
OFFSITE

R. Blaunstein

ERDA Div. of Biomedical and Environmental Research Washington, DC 20545

H. M. Busey

ERDA Div. of Military

Application

Washington, DC 20545

M. A. Bell

ERDA Div. of Safety

Standards and Compliance

Washington, DC 20545

ERDA Technical Information

Center

M. S. Kaminsky

Argonne National Laboratory $9700 \mathrm{~S}$. Cass Avenue

Argonne, IL 60439

V. A. Maroni

Argonne National Laboratory

9700 S. Cass Avenue

Argonne, IL 60439

P. M. Persiani

Argonne National Laboratory

9700 S. Cass Avenue

Argonne, IL 60439

M. Petrick

Engineering and Technology

Division

Argonne National Laboratory

9700 S. Cass Avenue

Argonne, IL 60439

W. E. Parkins, Manager

Atomics Internationa?

Component Engineering and

Technology Division

North American Rockwe 1]

P. 0. Box 309

Canoga Park, CA 91304

D. Gurinsky

Brookhaven National Laboratory

ERDA Brookhaven Area Office

Upton, NY 11973

H. J. Kouts

Brookhaven National Laboratory ERDA Brookhaven Area Office

Upton, NY 11973

S. Pearlstein

Brookhaven National Laboratory ERDA Brookhaven Area Office Upton, NY 11973
OFFSITE

J. R. Powell

Brookhaven National Laboratory ERDA Brookhaven Area Office Upton, NY 11973

A. J. Impink, Jr. Carnegie Mellon University

Pittsburgh, PA 15213

R. A. Gross

Plasma Research Laboratory

236 SW Mudd Bldg.

Columbia University

New York, NY 10027

W. C. Gough

Electric Power Research Inst

3412 Hillview Ave.

Palo Alto, CA 94304

G. R. Hopkins

Gulf General Atomic

P. 0 . Box 1111

San Diego, CA 92112

Zeinab Sabri

lowa State University

261 Sweeney Hall

Nuclear Engineering Department

Ames, IA 50010

R. Borg

Lawrence Livermore Laboratory

P.0. Box 808

Livermore, CA 94550

T. K. Fowler

Lawrence Livermore Laboratory

P.0. Box 808

Livermore, CA 94550

R. Moir

Lawrence Livermore Laboratory

P.0. Box 808

Livermore, CA 94550

A. Carl Haussmann

Lawrence Livermore Laboratory

P.0. Box 808

Livermore, CA 94550

J. Hovingh

Lawrence Livermore Laboratory

P.0. Box 808

Livermore, CA 94550

R. F. Post

Lawrence Livermore Laboratory

P.0. Box 808

Livermore, CA 94550

C. J. Taylor

Lawrence Livermore Laboratory

P.0. Box 808

Livermore, CA 94550 
R. Werner

Lawrence Livermore

Laboratory

P.0. Box 808

Livermore, CA 94550

L. L. Wood

Lawrence Livermore

Laboratory

P.0. Box 808

Livermore, CA 94550

W. Baver

Division Supervisor

of Physical Research

Sandia Labs Livermore

Livermore, CA 94550

L. Booth

Los Alamos Scientific

Laboratory

CTN Research

P.0. Box 1663

Los Alamos, NM 87544

D. J. Dudziak

Los Alamos Scientific

Laboratory

CTN Research

P.0. Box 1663

Los Alamos, NM 87544

D. B. Henderson

Los Alamos Scientific

Laboratory

CTN Research

P.0. Box 1663

Los Alamos, NM 87544

E. L. Kemp

Los Alamos Scientific Laboratory

CTN Research

P.0. Box 1663

Los Alamos, NM 87544

F. L. Ribe

Los Alamos Scientific

Laboratory

CTN Research

P.0. Box 1663

Los Alamos, NM 87544

L. Stewart

Los Alamos Scientific Laboratory

CTN Research

P.0. Box 1663

Los Alamos, NM 87544

K. Thomassen

Los Alamos Scientific

Laboratory

CTN Research

P.O. Box 1663

Los Alamos, NM 87544
0. K. Harling

Massachusetts Institute of

Technology

Cambridge, MA 02139

Bruno Coppi

Department of Physics

Massachusetts Institute of

Technology

Cambridge, MA 02139

L. Lidsky

Dept. of Nuclear Engineering

Massachusetts Institute of

Technology

Cambridge, MA 02139

Norm Rasmussen

Dept. of Nuclear Engineering

Massachusetts Institute of

Technology

Cambridge, MA 02139

David Rose

Massachusetts Institute of

Technology

Cambridge, MA 02139

R. E. Stickney

Mechanical Engineering

Massachusetts Institute of

Technology

Cambridge, MA 02139

J. J. Reinmann

NASA - Lewis Research Center

2100 Bookpark Rd.

Cleveland, OH 44135

Vincent Arp

National Bureau of Standards

Cryogenics Division

Boulder, CO 80302

J. F. Clarke

Oak Ridge National

Laboratory

P. 0. BoX Y

Oak Ridge, TN 37830

A. P. Fraas

Oak Ridge Nationa 1

Laboratory

P.O. Box Y

Oak Ridge, TN 37830

$\mathrm{J}$. Rand McNally, Jr. Oak Ridge National

Laboratory

P.0. Box Y

Oak Ridge, TN 37830

D. Steiner

Oak Ridge Nationa?

Laboratory

P. 0. Box Y

Oak Ridge, TN 37830
OFFSITE

J. Scott

Oak Ridge National Laboratory

P. 0. Box $X$

Oak Ridge, TN 37830

J. Banford

Physics International

2700 Merced St

San Leandro, CA 94577

R. A. Huse

Public Service Electric

and Gas Co.

80 Park Place

Newark, NJ 07101

M. Gottlieb

Princeton University, PPPL

P.0. Box 451

Princeton, NJ 08540

R. G. Mills

Princeton University

P.0. Box 45i

Princeton, NJ 08540

E. C. Tanner

Princeton University

P.0. Box 451

Princeton, NJ 08540

H. Perkins

Dept. of Chemistry

Princeton University

Princeton, NJ 06540

R. E. Gold

303 Sayre Hall

Forrestal Campus

P.0. Box 451

Princeton, NJ 06540

M. Kristiansen

Texas Tech. University

Lubbock, TX 79409

A. F. Haught

United Aircraft Research Lab.

United Aircraft Corporation

East Hartford, CT 06108

L. Levine

U.S. Naval Research Laboratory Washington, DC 20390

C. Z. Serpan, Jr.

U.S. Naval Research Laboratory Washington, DC 20390

Francis Chen

University of California

Electronics Research

Laboratory

College of Engineering

Berkeley, CA 94720 
A. J. Lichtenberg University of California Electronics Research Laboratory College of Engineering Berkeley, CA 94720

Dave Okrent

U.C.L.A.

Los Angeles, CA 90024

C. D. Hendricks University of Illinois Nuclear Engineering Laboratory

Urbana, IL 61801

G. H. Miley University of Illinois Nuclear Eng ineering Laboratory

Urbana, IL 61801

Terry Kammash University of Michigan Nuclear Engineering Department

Ann Arbor, MI 48105

Dean Abrahamson University of Minnesota School of Public Affairs

Social Science Building/309

Minneapolis, MN 55455

W. G. Davey

University of Texas

Department of Physics

Austin, TX 78712

E. Linn Draper, Jr. University of Texas Department of Physics Austin, TX 78712

W. E. Drummond University of Texas Department of Physics Alustin, TX 78712

Abraham Hertzberg University of Washington Aerospace Research Laboratory

316 Guggenheim Seattle, WA 98105

A. L. Babb University of Washington Nuclear Eng ineering Department

Seattle, WA 98105
R. Conn

University of Wisconsin Nuclear Engineering

Department

Madison, WI 53706

G. L. Kulcinski

University of Wisconsin Nuclear Engineering

Department

Madison, WI 53706

C. W. Maynard

University of Wisconsin Nuclear Engineering

Department

Madison, WI 53706

D. Lichtman

Department of Physics

University of Wisconsin

Milwaukee, WE 53201

E. E. Donaldson Washington State University Deparment of Physics

Pullman, WA 99163

D. D. Mahlum

Division of Biomedical and Environmental Research Washington, DC 20545

J. V. Vanston

Engineering Science

Building

University of Texas

Austin, TX 78712

Leslie S. Ramsey

450 North 5 th Street

Indiana, PA 15701 
ERDA Richland Operations Office

W. A. Burns

Atlantic Richfield Hanford Company

J. D. Kaser

Hanford Engineering

Development Labs

D. G. Doran

H. H. Yoshikawa

\section{Battelle-Northwest}

D. T. Aase

G. S. Allison

T. W. Ambrose

D. G. Atteridge

D. A. Baker

J. L. Bates

M. A. Bayne

E. R. Bradley

J. L. Brimhall

R. L. Brodzinski

R. J. Brouns

L. R. Bunnell

L. L. Burger

S. H. Bush

N. E. Carter

T. D. Chikalla

R. G. Clark

T. L. Criswell

S. D. Dahlgren

M. T. Dana

D. E. Deonigi

R. L. Dillon

D. A. Dingee

P. J. Dionne

B. H. Duarie

J. W. Finnigan

J. C. Fox

J. J. Fuquay

J. E. Garnier

R. D. Gasti1

B. F. Gore

25 J. N. Hartley

A. J. Haverfield

U. P. Jenquin

A. B. Johnson, Jr.

R. H. Jones

T. J. Kabele

W. S. Kelly

H. E. Kissinger

D. A. Kottwitz

N. Laegried

B. R. Leonard, Jr

D. L. Lessor

H. B. Liemohn

R. C. Lijkala

M. A. Mckinnon

R. F. Maness

R. P. Marshall
Battelle-Northwest - Continued

E. S. Murphy

R. D. Nelson

D. F. Newman

R. E. Nightingale

D. E. Olesen

L. T. Pedersen

R. T. Perry

D. R. Pratt

L. A. Rancitelli

J. F. Remark

U. S. Renné

R. E. Rhoads

W. D. Richmond

W. F. Sandusky

L. C. Schmid

N. M. Sherer

E. P. Simonen

R. I. Smith

J. K. Soldat

C. W. Stewart

K. B. Stewart

R. W. Stewart

J. A. Strand

D. L. Styris

A. M. Sutey

V. L. Teofilo

G. L. Tingey

M. T. Thomas

R. C. Thompson

L. H. Toburen

T. J. Trapp

$R$. Wang

R. E. Westerman

L. D. Williams

10 J. R. Young

M. G. Zimmerman

1 Technical Publications (BH)

5 Technical Information 